\title{
Vegetation of a tropical dry forest in a landscape with chronic disturbance: the case of the indigenous community of San Nicolás Zoyatlan (Guerrero, Mexico)
}

\author{
Virginia Cervantes-GutiérrezZ* ${ }^{1 *}$ Ignacio Méndez-RamíreZ², Iván E. \\ Roldán-Aragón ${ }^{1}$, Aurora Chimal-Hernández ${ }^{1}$, Vicente Arriaga- \\ Martínez ${ }^{3}$ and Julia CARABIAS-LILLO 4
}

Botanical Sciences 95 (3): 433-459, 2017

DOI: $10.17129 /$ botsci.1113

Copyright: (c) 2017 CervantesGutiérrez et al. This is an open access article distributed under the terms of the Creative Commons Attribution License, which permits unrestricted use, distribution, and reproduction in any medium, provided the original author and source are credited.

1 Depto. El Hombre y su Ambiente. Unidad Xochimilco, Universidad Autónoma Metropolitana.

2 Depto. Probabilidad y Estadística. Instituto de Investigaciones en Matemáticas Aplicadas y Sistemas, Universidad Nacional Autónoma de México.

${ }^{3}$ Comisión Nacional de Biodiversidad.

${ }^{4}$ Depto. Ecología y Recursos Naturales. Facultad de Ciencias, Universidad Nacional Autónoma de México.

* Corresponding author: mcervantes@correo.xoc.uam.mx

\section{Abstract}

Background: Tropical dry forests (TDF) provide numerous environmental services to its residents; this has led them to be humanized landscapes subjected to chronic disturbance with a high risk of disappearing.

Research question: To establish the relationship of vegetation structure and composition of a chronically disturbed TDF, with some environmental factors and the intensity of agricultural land use.

Study site and period of research: Our study was conducted during six months (July through November) in the TDF of the community of San Nicolas Zoyatlan (Guerrero, Mexico); a territory with a history of over 500 years of agricultural use. This use has led to a complex mosaic of vegetation fragments.

Methods: A selection of 36 fragments was studied to determine vegetation structure and composition as well as environmental factors. Representative plants from sampled areas were collected. Data gathered was explored with regression and multivariate statistical analysis techniques.

Results: A total of 59 families, 178 genera and 279 species were recorded. Species richness varied widely among fragments, in general with a low dominance and high turnover of species. Slope was the only factor that showed a solid relationship with vegetation variables. Three groups of fragments were established and the statistical differences between them were explained by the duration of fallow. The fragments with longer fallow period showed the best conditions in vegetation variables and $66.9 \%$ of the species were found in them.

Conclusions: Composition and structure of the tropical dry forests were related to intensity of agricultural land use. Although there is a process of impoverishment, vegetation dynamics involving species of the Fabaceae, Asteraceae and Burseraceae families show a potential for their use in the environmental restoration of Zoyatlan.

Keywords: Balsas watershed, chronic disturbance, composition and structure, intensity of agricultural use, potential species.

\section{Resumen}

Antecedentes: Los bosques tropicales secos (BTS) aportan numerosos servicios ambientales a sus habitantes, esto los ha llevado a ser paisajes humanizados sujetos a disturbio crónico con riesgo de desaparecer.

Pregunta: ¿Cuál es la relación de la composición y estructura de la vegetación de un BTS sujeto a disturbio crónico, con algunos factores del medio físico y la intensidad de uso agrícola del suelo?

Sitio de estudio y fecha: El estudio se realizó en la comunidad de San Nicolás Zoyatlan (Guerrero, México) durante seis meses (junio-noviembre). Este territorio cuenta con más de 500 años de uso agropecuario, lo que ha propiciado un complejo mosaico de fragmentos de vegetación.

Métodos: Se muestrearon 36 fragmentos para determinar la composición y estructura de la vegetación y los factores ambientales. Se recolectó y herborizó el material botánico representativo de las áreas muestreadas. Utilizando análisis de regresión y técnicas multivariadas se establecieron, tanto relaciones entre la vegetación y los factores ambientales como grupos específicos de fragmentos.

Resultados: Se registraron 59 familias, 178 géneros y 279 especies. Entre fragmentos la riqueza específica varío ampliamente presentándose una dominancia baja y un alto recambio de especies. Únicamente la pendiente mostró una relación consistente con las variables de vegetación. Se obtuvieron tres grupos de fragmentos cuyas diferencias estadísticas se explicaron por los periodos de descanso agrícola; las zonas con mayor tiempo de barbecho presentaron $66.9 \%$ de las especies y las mejores condiciones en las variables de vegetación.

Conclusiones: La composición y estructura de la vegetación del BTS estuvo relacionada con la intensidad de uso agrícola del suelo. Aunque se presenta un proceso de empobrecimiento de la vegetación, existe una dinámica en la que participan especies de las familias Fabaceae, Asteraceae y Burseraceae, con potencial para utilizarse en la restauración ambiental de Zoyatlan.

Palabras clave: composición y estructura, cuenca del Balsas, disturbio crónico, especies potenciales, intensidad de uso agrícola. 
ropical dry forests (TDF) are severely reduced in extension by human influence (Murphy \& Lugo 1986, Janzen 1988, Gentry 1995). Miles et al. (2006) indicate that $97 \%$ of their surface is threatened by the conversion to agricultural croplands; the increase of population density; the blazes caused by misuse of fires in agriculture; habitat fragmentation; and climate change. Likewise, Newton \& Tejedor (2011) also consider the accelerated urbanization of these areas as a threat.

TDFs still cover 3,178,000 $\mathrm{km}^{2}$ across the world (Bezaury 2010); almost half is located in developing countries (UNDP 2004) and $8.8 \%$ in Latin America and the Caribbean (Bezaury 2010). In this region, an important part of the inhabitants depends directly on environmental services of the forest. Weather and soil fertility of these areas also offer proper conditions for the development of several types of crops (Murphy \& Lugo 1986). In Mexico, the presence of settlements in TDFs is related to the process of domestication of many food and medicinal plant species (Argueta 1994, Casas et al. 1994, Challenger 1998, Hernández-X 1998, Soto 2010); for this reason, they play a unique role in the social and economic context. Estimates indicate that people living in this kind of forests use a great number of vegetation species for their benefit (Dorado et al. 2002, Guízar-Nolazco et al. 2010).

In Mexico, TDFs stand out for their floristic diversity (Lott et al. 1987, Gentry 1995); approximately $20 \%$ of Mexican flora is present in this type of vegetation (Rzedowski 1991a). Besides their great number of endemism (Rzedowski 1991b), TDFs are characterized as the richest forests of the world (Bezaury 2010, Rzedowski \& Calderón 2013). Unfortunately, deforestation and fragmentation caused by agriculture contribute to their degradation (Rzedowski \& Calderón 1987, Trejo \& Dirzo 2000, Trejo 2010), as well as other less known social and environmental threats.

Regardless of the importance for the conservation of biodiversity and for the environmental services that sustain a considerable part of Mexico's rural population (Toledo et al. 1989, Toledo \& Ordoñez 1998, Dorado et al. 2002), the knowledge of the floristic, vegetation structure and composition, their current situation and change dynamics, as well as of the forces that promote their degradation is limited (Trejo 1998, 2010, Cervantes et al. 2001, Quesada et al. 2009). Although this tendency is changing, knowledge is focused only in few places of the country (Noguera et al. 2002, Gallardo-Cruz et al. 2005, Maass et al. 2005, 2010, Álvarez-Yépiz et al. 2008, Lebrija-Trejos et al. 2008) and reference to the causes of disturbance, when present, is superficial (Quesada et al. 2009).

It has been suggested that chronic disturbance in TDFs can have effects of similar magnitude to those of an acute disturbance (Singh 1998); hence, it is indispensable to recognize that these ecosystems are part of a matrix of humanized landscapes that are exposed to chronic disturbance. Thus, it is necessary to research on the causes of disturbance and the use forms of the human populations in the socio-ecological systems; this will help to ascertain the influence of management in the maintenance of the vegetation dynamics and to ponder the opportunities for conservation and restoration of these systems.

This paper approaches the analysis of the composition, structure and diversity of the TDF of the community of San Nicolás Zoyatlan. The investigation integrates: (1) a descriptive analysis of vegetation and the elaboration of a species list; (2) the relationship of the composition and structure of the vegetation with some environmental factors and the intensity of agricultural land use; and (3) the identification of species groups that may allow to ascertain the state and dynamics of the vegetation, as well as the potential for their use in restoration actions.

\section{Materials and methods}

Research area. The rural community of San Nicolás Zoyatlan is part of Xalpatlahuac, one of 19 municipalities that shape the region called "La Montaña" in the State of Guerrero (Figure 1); this region is part of the Balsas watershed. The climate is semi-warm, sub-humid and annual average temperature is $27.5^{\circ} \mathrm{C}$ with no frosts (García 1998). The rainy season occurs during summer, with average annual precipitation of $781 \mathrm{~mm}$ and a P/T ratio of 30.2. November to April is a period of water shortage, while the rainy season is from May to October. Zoyatlan covers an area of 924 hectares with a complex terrain characterized by altitudes ranging from 1,300 to $1,800 \mathrm{~m}$ a.s.l., a morphology of hills and summits in $83.62 \%$ of the total surface, as well as 
Figure 1. Location of the indigenous community of San Nicolás Zoyatlan, Gro. Mexico. The figure also shows the position of the fragments where vegetation sampling was done.

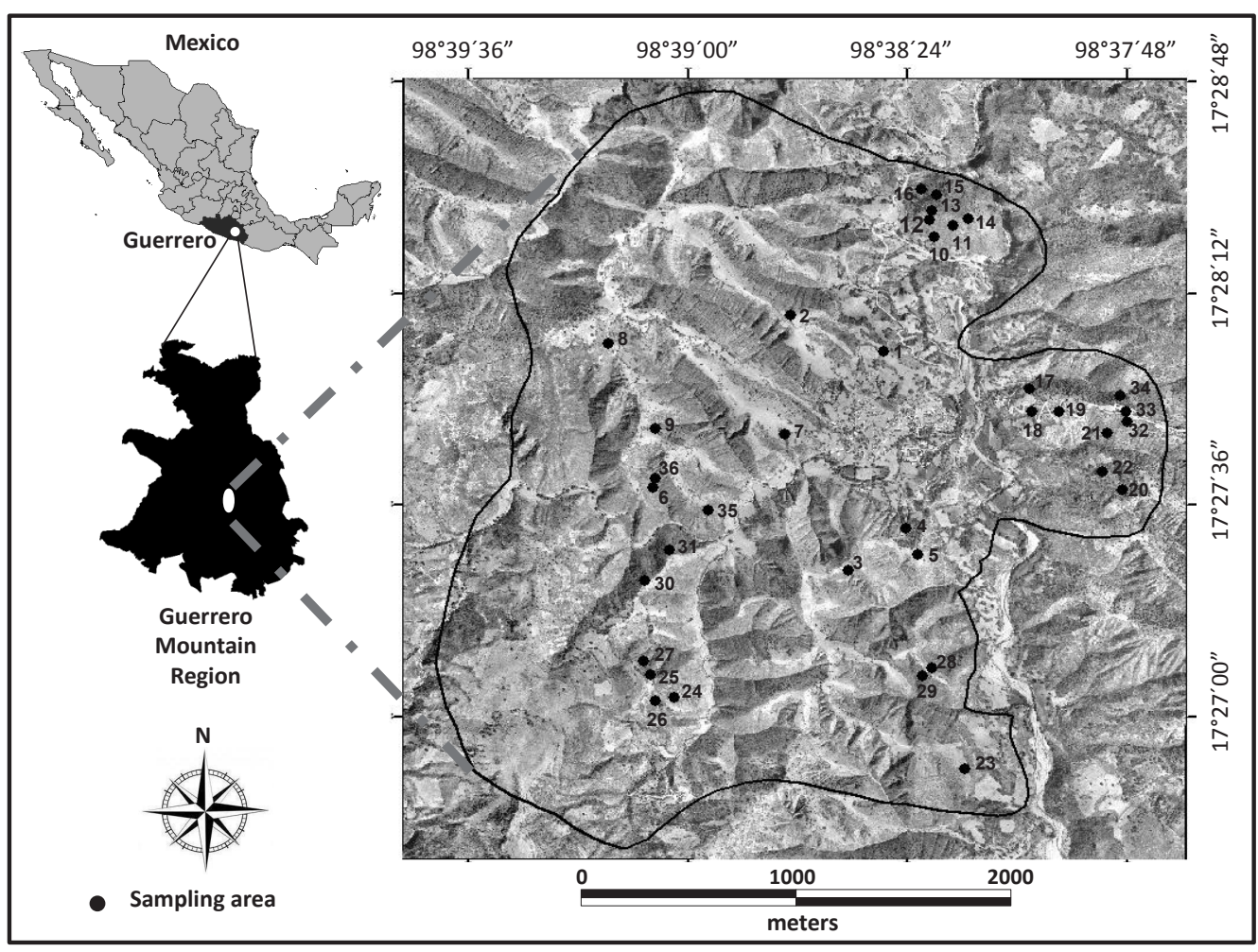

slopes higher than $10^{\circ}$ dominating $70 \%$ of the landscape. Lithology is very diverse with materials of volcanic and sedimentary origin (Cervantes et al.2014). Soils are shallow and rocky and are classified as Anthropic Regosol and Mollic Leptosol (Cervantes et al.2005).

Zoyatlan has a long story of use of natural resources. The population is mostly of Nahua origin and the record of their settlements goes back to 1490 (Vega 1991). It is estimated that the factors that have contributed to the reduction of the vegetation cover in the territory are: transhumant flocks (which began with the Spanish conquest); the conflicts of land invasion at the beginning of the XX century and their negative impact both in the physical and biotic environment of the socio-ecological system, and in the disintegration of agricultural production systems (Cervantes \& De Teresa 2004). In 1998 the main activities were subsistence farming, animal husbandry of goats, the collection of forest products and migration. Agriculture has been practiced with different intensities of land use and various agronomic practices (Cervantes et al. 2014) that are influenced by soil quality, water availability, landforms and socioeconomic aspects related with the production unit (Cervantes et al. 2005). Family ranching has been developed in fallow land and forest areas that belong to the owners of the herds. In 1998 the most important forestry activity carried out by the families in the community was firewood collection (Cervantes et al. 2014).

In 1998 Zoyatlan had 681 inhabitants organized in 116 families. That year, human settlements covered $3.17 \%$ of the total area whereas agricultural use $25.9 \%$. Although $70.8 \%$ of the surface had some type of woody vegetation of Juniperus forest, riparian forest, and TDF, their condition and cover was represented in scattered fragments. Considering its extent, TDF is the most represented vegetation type since it occupies $65.1 \%$ of the total area. However, only two fragments with 8.08 ha were found in a moderately preserved condition; the remainder (591.72 ha) was represented by secondary TDF (Cervantes et al. 2014).

Vegetation sampling. With the use of the topographic map (1: 50,000; Xalpatlahuac E14D32) and aerial photographs $(1: 80,000 ; 1979) 58$ fragments with different vegetation cover (grassland, herbs, shrubs and trees of TDF) were initially identified. This information was verified during four field trips, and 36 fragments were selected with the following criteria: a) that the different vegetation types were distributed across the combinations of relief and lithology type; and b) that fragment size was $\geq 513 \mathrm{~m}^{2}$ (Figure 1). 
Between June and November 1994, 12 plots of $3 \times 3 \mathrm{~m} \mathrm{(108} \mathrm{m}^{2}$ in total) were sampled and subplots were separated by $5 \mathrm{~m}$ between each other. In the higher right corner of each subplot, smaller plots of $1 \times 2 \mathrm{~m}\left(24 \mathrm{~m}^{2}\right.$ in total $)$ were sampled. In each sampling area, physical environment factors -altitude, aspect, landform and slope- were recorded.

According to vegetation physiognomy, two layers were distinguished. Top layer (recorded in $3 \times 3 \mathrm{~m}$ squares) included trees, shrubs, and succulent plants, with height $\geq 0.60 \mathrm{~m}$. Species composition, percentage of cover per species, number of individuals per species and height were also recorded. Bottom layer included herbaceous plants and seedlings of other life forms: in $1 \times$ $2 \mathrm{~m}$ squares species composition and percentage of cover per species was recorded and average height calculated. All species collected were pressed in the field and for taxonomic identification the specimens were matched in the herbariums of the Faculty of Sciences at UNAM, and MEXU; specialists for each taxonomic group were consulted.

Intensity of agricultural land use. To determine the use intensity of vegetation fragments, it was necessary to identify landowners. To this purpose, information from the genealogic inquiries done by Cervantes \& De Teresa (2004) was used. In addition to this, research on the characterization of Zoyatlan production systems (Cervantes et al. 2005, 2014) was used to understand better the particularities of agricultural management in the area.

Data analysis. Vegetation data were processed using conventional methods (Mueller-Dombois \& Ellenberg 1974, Matteucci \& Colma 1982). Frequency and cover (absolute and relative) per fragment and species, as well as their importance value index (IVI = relative frequency specie $\mathrm{i}$ + relative cover specie i) were calculated for both layers. To describe physiognomy and the effect of use in stratification, height data in the top layer was separated in two ranges ( $\leq 2 \mathrm{~m}$; and $>$ $2 \mathrm{~m}$ ). For the analysis of diversity, species richness (S), diversity index of Shannon-Wiener $\log _{2}$ (H') and Simpson index (D) as a measure of dominance $\left(\lambda=\sum \mathrm{pi}^{2}\right)$, were obtained.

To identify the formation of groups of species composition between the fragments, the method of non-hierarchical K-means clustering (Afifi \& Clark 1997) was used. This analysis was based on the average percentage cover values per species - only from those species in the top and bottom layers that were present in four or more fragments - . To confirm the existence of significant differences between the groups, analysis of variance (ANOVA) were applied with the groups as an independent variable, and the Euclidean distances between and within groups (obtained in the analysis of K-means) as the dependent variable.

To explore the relationship between environmental factors of the fragments and vegetation variables, regression analyses (Montgomery 1991) were made relating altitude, lithology, aspect and slope with total cover (TCO) and total richness of species (TSR) and families (TFR). Where a statistically significant relationship was found, variables and factors were selected for a cluster analysis using Ward's hierarchical clustering technique (Everitt \& Dunn 1991, Johnson 2000). Subsequently, univariate or multivariate variance analysis (ANOVA or MANOVA) were applied to identify significant differences between the groups formed by the classification analysis. In both cases, groups obtained by the method of Ward were used as independent variables, and the vegetation or environmental factors as dependent variables. To display the formation of the groups that differed statistically, biplots (canonical centroid plot; SAS 1989) were made in a two-dimensional canonical space.

\section{Results}

Floristic composition. The floristic list of Zoyatlan includes 316 morphospecies (hereinafter species; Appendix 1) located predominantly in the Magnoliopsida class. Almost all specimens (except $5.06 \%$ ) were determined to some taxonomic level: $94.94 \%$ (300) to family; $88.29 \%$ (279) to genus; and $74.68 \%$ (236) to species. Overall, the samples include 59 families, 178 genera and 279 species (Table 1).

From the 59 families, 29 were represented by a single species (Appendix 1); 12 of these families had five or more species and gather $64.61 \%$ of total genera and $74.19 \%$ of all species. The families that are best represented considering the number of genera and species are Asteraceae, Fabaceae and Poaceae. Only in 10 genera, four or more species were found (Table 1).

Although 59 species are shared between the two layers (215 were exclusive to the bottom 
Table 1. Floristic composition in the community of San Nicolás Zoyatlan, Gro. Mexico. Numbers in brackets indicate

the number of taxa where the species could not be determined. No. FR = number of fragment.

\begin{tabular}{llcc} 
GROUP & FAMILIES & GENERA & SPECIES \\
\hline Magnoliophyta & & & $202(+34)$ \\
$\quad$ Magnoliopsida & 45 & 145 & $29(+8)$ \\
$\quad$ Liliopsida & 10 & 27 & 1 \\
$\begin{array}{l}\text { Pinophyta } \\
\text { Pteridophyta }\end{array}$ & 1 & 1 & $0 \quad(+1)$ \\
$\quad$ Lycopodiopsida & 1 & 1 & 4 \\
$\quad$ Polypodiopsida & 2 & 4 & $236(+43)$ \\
TOTAL & 59 & 178 & \\
\hline
\end{tabular}

\begin{tabular}{llcc}
\hline FAMILIES (5 or more species) & & \\
Magnoliopsida & Acanthaceae & 6 & 6 \\
& Asteraceae & 35 & 55 \\
& Boraginaceae & 6 & 6 \\
& Burseraceae & 1 & 7 \\
& Convolvulaceae & 3 & 8 \\
& Euphorbiaceae & 5 & 14 \\
& Fabaceae & 29 & 57 \\
& Lamiaceae & 2 & 8 \\
& Malvaceae & 6 & 10 \\
Liliopsida & Rubiaceae & 3 & 6 \\
\hline & Verbenaceae & 4 & 7 \\
& Poaceae & 15 & 23 \\
\hline
\end{tabular}

GENERA (4 or more species) Magnoliopsida

$\begin{array}{ll}\text { Magnoliopsida } & \text { Asteraceae } \\ & \text { Burseraceae } \\ \text { Convolvulaceae } & \text { Euphorbiaceae } \\ \text { Fabaceae } \\ \text { Fabaceae } \\ \text { Fabaceae } \\ \text { Fabaceae } \\ \text { Lamiaceae } \\ \text { Malvaceae }\end{array}$

PRESENCE OF SPECIES IN FRAGMENTS

No. $\mathbf{F R}$
1
2 a 3
4 a 8
9 a 18
19 a 27
28 a 34

and 26 species to the top layer; Appendix 1), none was found in all 36 sampling sites. More than half of the species were found in one to three fragments (Table 1) and only five species $(1.66 \%)$ were found in at least $80 \%$ of the fragments (between 29 and 34 sampling sites): Bidens aurea and Sanvitalia procumbens (Asteraceae), Acacia cochliacantha (Fabaceae), Loeselia coerulea (Polemoniaceae) and Bouteloua curtipendula var. caespitosa (Poaceae) (Appendix 1).

Richness and diversity. The average species richness ( \pm 1 SD) of all 36 fragments was 48.28 \pm 18.52 (range: 11-93). For the bottom layer, values were distributed from 11 to 79 and for the top layer from 1 to 28 species (Table 2). Similar trends were established for Shannon diversity index, with values for the bottom layer ranging from 2.60 to 5.64 and for the higher from 0 to 3.99. In both layers there was a strong positive linear relationship between species richness and diversity index (bottom layer: $R^{2}=0.85, F=192.24, p<0.0001$; top layer: $R^{2}=0.77, F=97.68$, $p<0.0001)$. With regard to Simpson's index, values obtained indicate low dominance, with the exception of five fragments where the values for the top layer were $\geq 0.52$ (Table 2).

Vegetation structure. The bottom layer was the only one well represented in all 36 fragments since for six of them, the top layer was absent and, in another four it was represented only by individuals $\leq 2 \mathrm{~m}$ high (Table 3 ). 
Table 2. Environmental characteristics and species richness, diversity and dominance values for vegetation fragments (VF) studied in the community San Nicolás Zoyatlan, Gro. Mexico. LI = Lithology (QBR - Quartzitic breccia, VBR - Volcanic breccia, AND - Andesite, LAN Limestone-Andesite, LIM - Limestone, SAC - Sandstones conglomerate, TUF - Tuff); AL = Altitude; SL = Slope; AS = Aspect (S - South, N North, E - East, W - West); LF = Landform (H - Hillside, Ge - Gentle, St - Steep, VS - Very steep, ES - Extended Summit, Ter - Terrace); Sr = Species richness; $\mathrm{H}^{\prime}=$ Shannon-Wiener Diversity Index $\log ^{2} ; \mathrm{D}=$ Simpson Index.

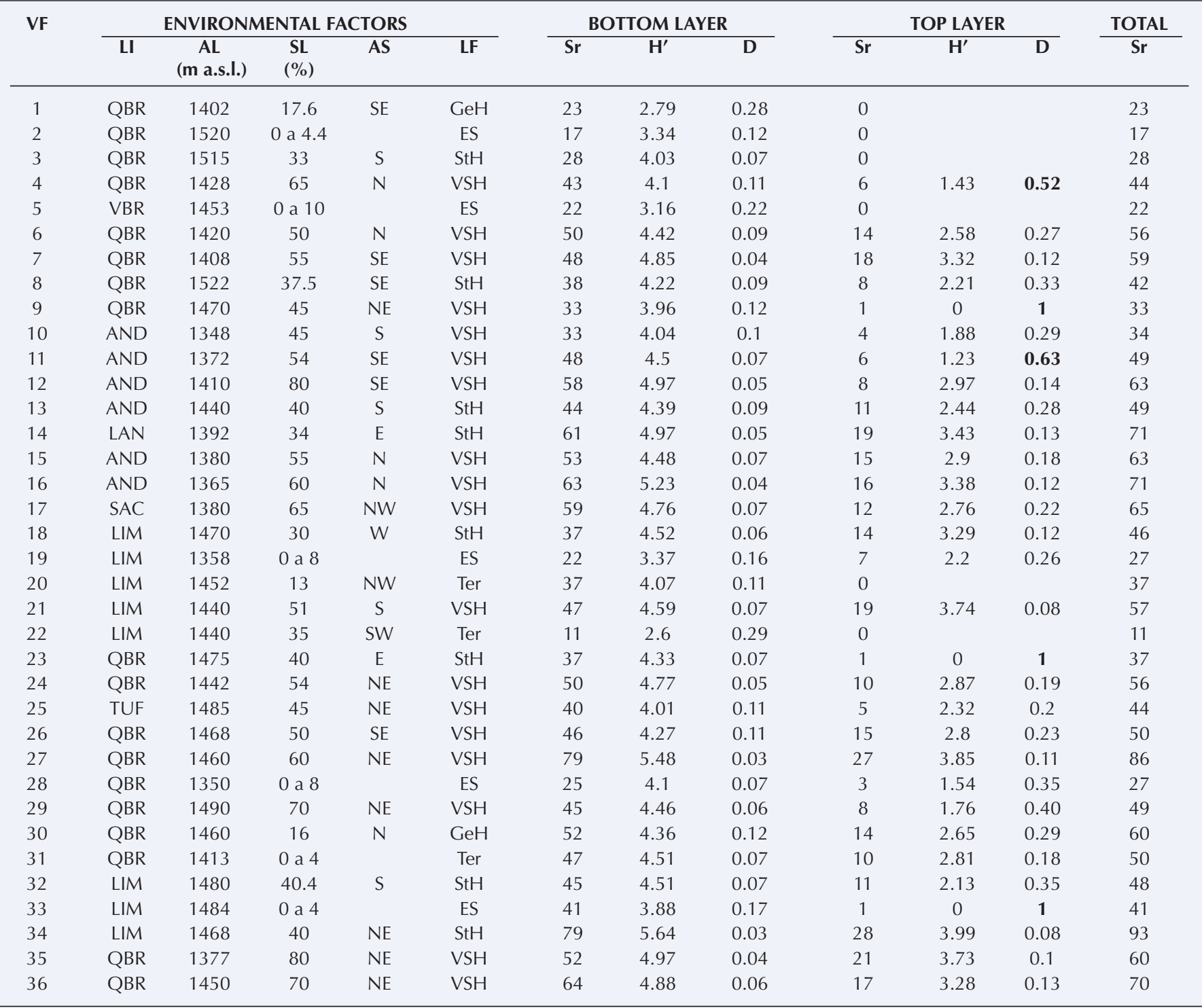

Average height ( $\pm 1 \mathrm{SD}$ ) for the bottom layer was $0.174 \pm 0.06 \mathrm{~m}$ (range: 0.07 to $0.34 \mathrm{~m})$. For individuals in the top layer with size $\leq 2 \mathrm{~m}$, height ranged from 0.53 to $1.90 \mathrm{~m}$, with an average of $1.08 \pm 0.45 \mathrm{~m}$; in the case of those $>2 \mathrm{~m}$ this value was three times higher: $3.33 \pm 0.43 \mathrm{~m}$, with heights ranging from 2.23 to $4.21 \mathrm{~m}$ (Table 3 ).

Regarding the number of individuals in the two established height intervals, sharp contrast was found between and within the fragments. For $\leq 2 \mathrm{~m}$, the mean value $( \pm 1 \mathrm{SD})$ was $65 \pm$ 70.45 ; the dispersion of the data with respect to the average value is due to the fact that the number of individuals between fragments ranged from 2 to 316 ; in the case of the $>2 \mathrm{~m}$ interval, this number was significantly lower: $18.04 \pm 14.21$, with variations ranging from 1 to 44 individuals (Table 3).

There are also differences in the cover values between fragments and layers (Figure 2). In the bottom layer it ranged from 42.8 to $108.6 \%$, but only in six fragments cover was $>90 \%$. In the top layer, the dominant tendency was of low cover values, although they ranged from 0.4 to $107.9 \%$. For individuals $\leq 2 \mathrm{~m}$ in height, cover was $>50 \%$ only in three fragments; as for 
Table 3. Average height of vegetation in bottom and top layers, number of individuals and species as well as importance value index (IVI) obtained in the fragments (FR) of San Nicolás Zoyatlan community, Gro. Mexico. Ind = individuals; Sp = species; No. = number. The number in parenthesis besides the IVI corresponds to the name of the species: (1) A. dentata, (2) S. amplexicaulis, (3) E. prostrata, (4) B. curtipendula var. caespitosa, (5) B. repens, (6) D. hegewischiana, (7) D. tagetiflora, (8) L. graveolens, (9) T. stans, (10) O. atropes, (11) I. arborescens, (12) B. copallifera, (13) A. pennatula, (14) A. bilimekii, (15) A. cochliacantha, (16) A. farnesiana, (17) J. flaccida.

\begin{tabular}{|c|c|c|c|c|c|c|c|c|c|c|}
\hline \multirow{3}{*}{$\begin{array}{c}\text { No. } \\
\text { Fragment }\end{array}$} & \multirow{2}{*}{\multicolumn{2}{|c|}{ Bottom layer }} & \multicolumn{7}{|c|}{ Top layer } & \multirow[b]{3}{*}{$\begin{array}{l}\text { IVI } \\
(\%)\end{array}$} \\
\hline & & & & Size cla & $\leq 2 \mathrm{~m}$ & & & Size cla & $2 \mathrm{~m}$ & \\
\hline & $\begin{array}{l}\text { Height } \\
\text { (m) }\end{array}$ & $\begin{array}{l}\text { IVI } \\
(\%)\end{array}$ & $\begin{array}{l}\text { Height } \\
\text { (m) }\end{array}$ & $\begin{array}{l}\text { Ind. } \\
\text { (No.) }\end{array}$ & $\begin{array}{c}\text { Species } \\
\text { (No.) }\end{array}$ & $\begin{array}{l}\text { IVI } \\
(\%)\end{array}$ & $\begin{array}{l}\text { Height } \\
\text { (m) }\end{array}$ & $\begin{array}{l}\text { Ind. } \\
\text { (No.) }\end{array}$ & $\begin{array}{l}\text { Species } \\
\text { (No.) }\end{array}$ & \\
\hline 1 & 0.120 & $99.20(1)$ & 0.00 & 0 & 0 & & 0.00 & 0 & 0 & \\
\hline 2 & 0.124 & & 0.00 & 0 & 0 & & 0.00 & 0 & 0 & \\
\hline 3 & 0.161 & & 0.00 & 0 & 0 & & 0.00 & 0 & 0 & \\
\hline 4 & 0.170 & $53.69(2)$ & 0.95 & 21 & 5 & & 3.83 & 38 & 1 & $139.89(14)$ \\
\hline 5 & 0.717 & 89.08 (3) & 0.00 & 0 & 0 & & 0.00 & 0 & 0 & \\
\hline 6 & 0.172 & & 1.17 & 32 & 12 & & 4.21 & 39 & 3 & $93.66(14)$ \\
\hline 7 & 0.212 & & 1.35 & 168 & 13 & & 3.48 & 44 & 11 & \\
\hline 8 & 0.242 & & 0.97 & 174 & 8 & $108.20(8)$ & 3.64 & 5 & 3 & \\
\hline 9 & 0.129 & $61.74(4)$ & 1.84 & 9 & 1 & $200.00(9)$ & 0.00 & 0 & 0 & \\
\hline 10 & 0.159 & $52.51(4)$ & 0.75 & 4 & 3 & $\begin{array}{l}75.71(11) \\
62.86(10)\end{array}$ & 3.50 & 1 & 1 & \\
\hline 11 & 0.190 & & 1.58 & 26 & 5 & $157.10(11)$ & 3.18 & 9 & 4 & \\
\hline 12 & 0.163 & & 0.99 & 29 & 7 & $51.81(12)$ & 3.34 & 19 & 8 & \\
\hline 13 & 0.123 & $51.66(5)$ & 0.83 & 37 & 11 & 91.15 (10) & 2.66 & 6 & 3 & \\
\hline 14 & 0.195 & & 0.99 & 83 & 18 & & 3.04 & 16 & 6 & \\
\hline 15 & 0.153 & & 0.68 & 44 & 14 & $52.20(13)$ & 2.60 & 6 & 5 & \\
\hline 16 & 0.171 & & 1.10 & 66 & 15 & & 3.63 & 19 & 7 & \\
\hline 17 & 0.125 & & 1.09 & 55 & 12 & & 3.08 & 18 & 3 & 85.55 (17) \\
\hline 18 & 0.178 & & 1.18 & 131 & 12 & & 3.60 & 10 & 4 & \\
\hline 19 & 0.800 & 70.77 (14) & 1.24 & 41 & 7 & 58.91 (14) & 2.23 & 4 & 2 & 74.26 (13) \\
\hline 20 & 0.145 & $53.39(3)$ & 0.00 & 0 & 0 & & 0.00 & 0 & 0 & \\
\hline 21 & 0.162 & & 1.22 & 176 & 18 & & 3.58 & 35 & 8 & \\
\hline 22 & 0.340 & $103.43(6)$ & 0.00 & 0 & 0 & & 0.00 & 0 & 0 & \\
\hline 23 & 0.186 & & 1.90 & 7 & 1 & 200.00 & 3.00 & 1 & 1 & \\
\hline 24 & 0.152 & & 0.82 & 15 & 9 & & 3.50 & 1 & 1 & 75.37 (16) \\
\hline 25 & 0.149 & $51.20(7)$ & 0.53 & 5 & 5 & & 0.00 & 0 & 0 & \\
\hline 26 & 0.174 & $62.30(4)$ & 0.99 & 96 & 15 & $86.34(8)$ & 3.12 & 8 & 3 & \\
\hline 27 & 0.328 & & 1.25 & 120 & 24 & & 4.10 & 20 & 10 & \\
\hline 28 & 0.121 & & 0.77 & 3 & 3 & $\begin{array}{c}77.78(14), \\
77.78(9)\end{array}$ & 0.00 & 0 & 0 & \\
\hline 29 & 0.201 & & 1.21 & 24 & 6 & $56.07(9)$ & 3.45 & 14 & 3 & $113.99(14)$ \\
\hline 30 & 0.181 & $63.79(4)$ & 0.87 & 35 & 12 & & 3.31 & 12 & 3 & $103.98(14)$ \\
\hline 31 & 0.177 & & 0.95 & 36 & 9 & 58.88 (15) & 3.25 & 3 & 3 & \\
\hline 32 & 0.144 & & 1.20 & 48 & 10 & & 3.38 & 41 & 2 & $111.82(14)$ \\
\hline 33 & 0.111 & $80.52(3)$ & 0.55 & 2 & 1 & 200.00 & 0.00 & 0 & 0 & \\
\hline 34 & 0.253 & & 1.27 & 82 & 25 & & 3.46 & 35 & 11 & \\
\hline 35 & 0.321 & & 1.22 & 316 & 16 & & 3.20 & 44 & 14 & \\
\hline 36 & 0.171 & & 0.92 & 157 & 15 & & 3.22 & 21 & 6 & \\
\hline Mean & 0.174 & & 1.08 & 65.00 & 10.24 & & 3.33 & 18.04 & 4.85 & \\
\hline \pm 1S.D. & 0.061 & & 0.44 & 70.45 & 6.76 & & 0.43 & 14.64 & 3.56 & \\
\hline Median & 0.010 & & 1.09 & 37.00 & 10.00 & & 3.36 & 15.00 & 3.00 & \\
\hline
\end{tabular}

those $>2 \mathrm{~m}$, this occurred in nine - for both cases, cover was $>100 \%$ only in fragment $35-$. Thus the total cover between all 36 fragments was very dissimilar (ranging from 51 to $304 \%$ ), although average total cover $( \pm 1$ SD) was $122.89 \pm 54.39$. Cover values close to $100 \%$ were found in several places that did not had a top layer; in others, it was similar or slightly higher than $100 \%$ even if there was a top layer. Total cover values above $200 \%$ (Figure 2) were found in four fragments only $(7,27,34$ and 35$)$; in these, there was a well-developed top layer in both height intervals; mostly in accordance with the highest values for number of individuals and species (Table 3 ). 
Figure 2. Proportion of vegetation cover of the bottom layer (Bot Lay) and top layer (Top Lay) in the vegetation fragments studied in San Nicolás Zoyatlan, Gro. Mexico. Top Lay-1: includes individuals with heights $\leq 2 \mathrm{~m}$; Top Lay-

2: includes individuals with heights $>2 \mathrm{~m}$.

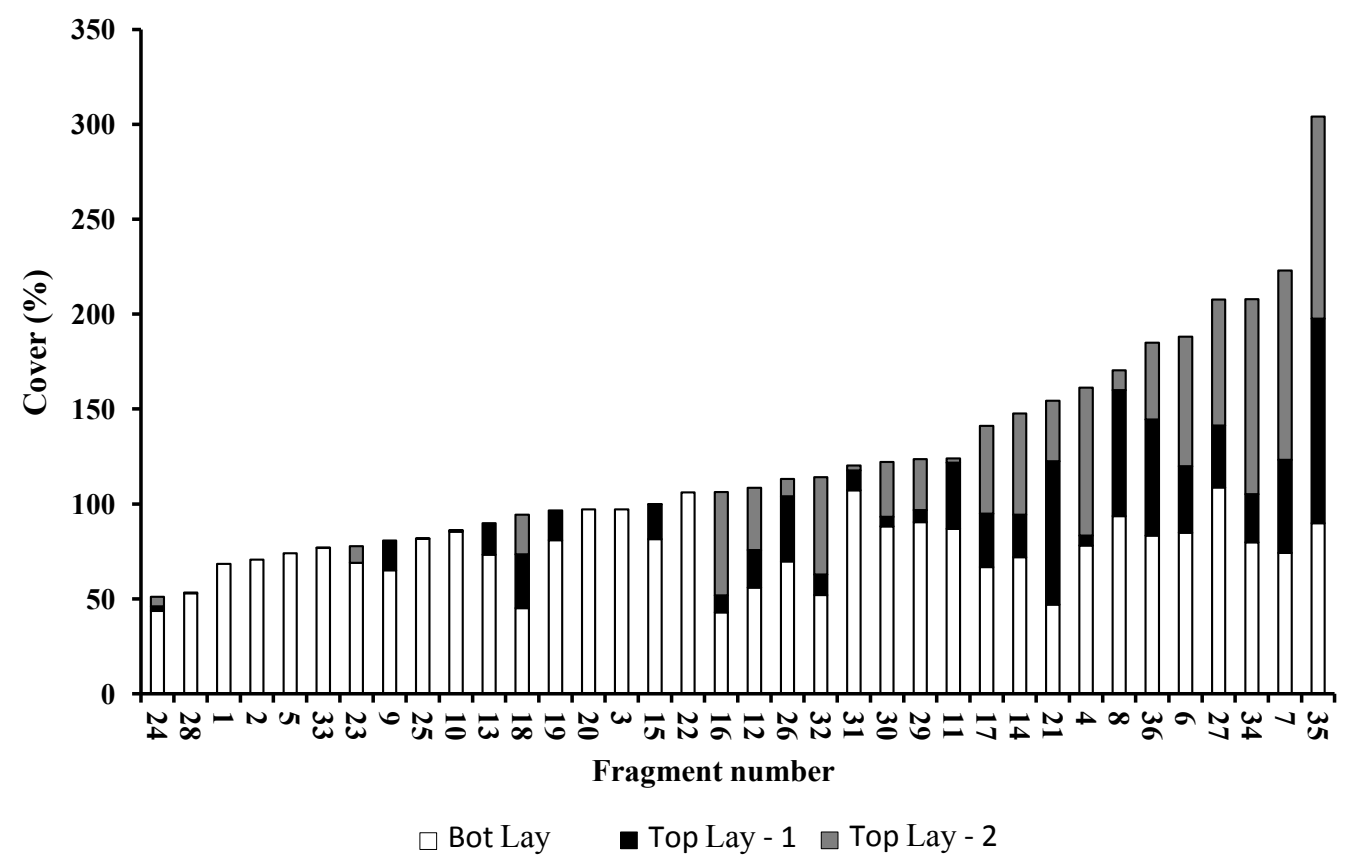

The importance value index (IVI) showed very low values; only 17 species $(6.09 \%)$ had IVI $\geq 50(1 / 4$ of the expected value of the IVI $=200)$. However, only eight did so in at least two fragments (Table 3). In the bottom layer, species that stood out were Aldama dentata, Dyssodia tagetiflora, Simsia amplexicaulis (Asteraceae), Euphorbia prostrata (Euphorbiaceae), Dalea hegewischiana (Fabaceae), Bouteloua curtipendula var. caespitosa and B. repens (Poaceae). Outstanding species in the top layer were Acacia bilimekii, A. cochliacantha, A. farnesiana, A. pennatula (Fabaceae), Bursera copallifera (Burseraceae), Ipomoea arborescens (Convolvulaceae), Juniperus flaccida (Cupressaceae), Lippia graveolens (Verbenaceae), Opuntia atropes (Cactaceae) and Tecoma stans (Bignoniaceae).

Intensity of agricultural land use. From previous research on the history of use of the fragments, we could corroborate that all of them are or were used for agriculture. However, duration of the fallow periods is a distinctive variable that characterizes semi-intensive agricultural systems of Zoyatlan into four distinctive use type. Use1 (U-1) - agriculture with fallow periods of 1 to 4 years without residual woody vegetation (fragments 1, 2, 3, 5, 20, 22 ); Use2 (U-2) agriculture with fallow periods of 1 to 4 years with residual woody vegetation (fragments 9,10 , $11,15,19,23,24,25,28,31,33$ ); Use 3 (U-3) - areas with fallow periods of 8 to 10 years (fragments 4, 6, 12, 13,14, 16, 18, 26, 30); and Use4 (U4) - areas with fallow periods of more than 10 years (fragments $7,8,17,21,27,29,32,34,35,36$ ).

Floristic composition clusters (FCC). Based on the analysis of $\mathrm{K}$-means applied to species that were present in four or more vegetation fragments, three clusters for the two layers were identified (Table 4). In the bottom layer the count was of 120 species, and 51 (42.5\%) occurred in all three clusters (Appendix 1). Cluster-1 grouped 28 fragments including species that are shared by the three groups and other 69 species; from the latter 10 were unique to this group: Acacia pennatula, Aeschynomene americana, Dalea foliolosa, Indigofera jamaicensis (Fabaceae), Calea hypoleuca, Zinnia violacea (Asteraceae), Euphorbia hirta (Euphorbiaceae), Lantana camara (Verbenaceae), Ruellia hookeriana (Acanthaceae) and Sida angustifolia (Malvaceae). Clusters 2 and 3 grouped few fragments (5 and 3 respectively) and fewer species (91 and 69 respectively). Although species 40 and 18 are different to those that are shared by all three clusters, they are part of Cluster-1 (Appendix 1); perhaps this is why there were no significant differences among these clusters (Table 4).

The top layer had 27 species and, although $21(77.8 \%)$ were common to all three clusters (Appendix 1); there were significant differences between clusters (Table 4). Cluster-2 differs statistically from Clusters 1 and 3; it stands out because it gathers 21 fragments and incorporates 
Table 4. Clusters of the fragments for the K-means analysis in the floristic composition of the bottom and top layers, and for the cluster analysis of the slope and the vegetation variables: total species and family richness and total cover. Also, results are shown of the ANOVA for the K-means analysis (ID = initial distance and $\mathrm{MD}=$ maximum distance for the cluster formation) and for the cluster with slope and vegetation variables independently, as well as the MANOVA for the combination of these variables. The asterisk indicates significant differences with $p<0.05$; different letters indicate significant differences between groups according to Tukey-Kramer multiple means comparison test. The marks in the number of fragments indicate the land use types: $X=$ agriculture with fallow periods of 1 to 4 years without residual woody vegetation $(U-1)$; $\underline{X}=$ agriculture with fallow periods of 1 to 4 years with residual woody vegetation $(\mathrm{U}-2) ; \mathrm{X}^{*}=$ areas with fallow periods of 8 to 10 years $(\mathrm{U}-3)$; $\mathrm{X} \bullet=$ areas with fallow periods of more than 10 years $(U-4)$.

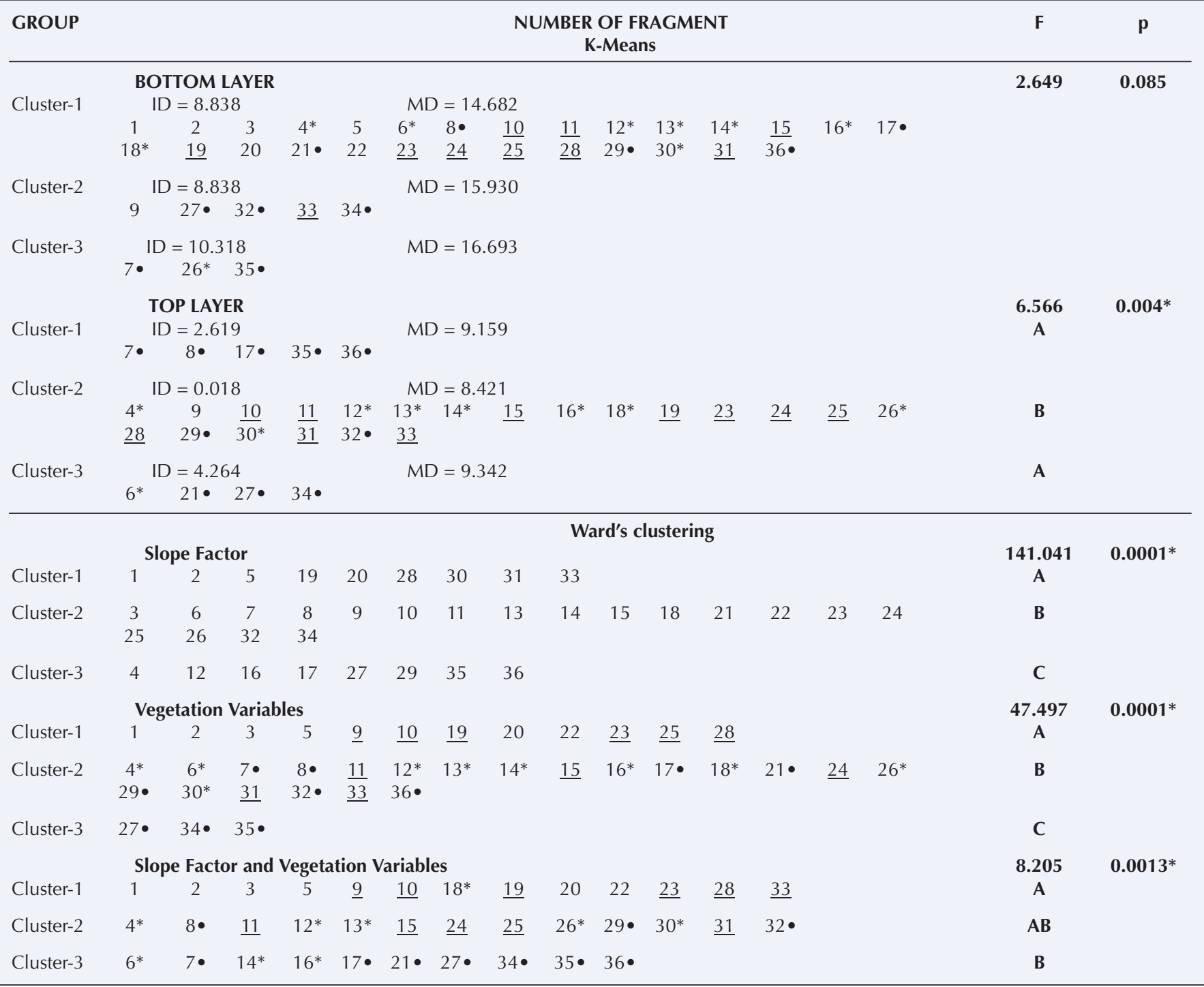

the 27 participant species, including two that only show up at this cluster: Bunchosia canescens (Malpighiaceae) and Cordia curassavica (Boraginaceae). Clusters 1 and 3 were not statistically different; the first brought together five fragments and the second four. Both clusters had 23 species; 21 common to all three clusters and two more in each case: Cluster-1 Heliocarpus velutinus (Malvaceae) and Tournefortia hirsutissima (Boraginaceae); Cluster-3 Lippia dulcis (Verbenaceae) and Mimosa polyantha (Fabaceae) (Appendix 1).

Vegetation and environmental factors. The relationship between lithology and aspect factors with vegetation variables was weak (Table 5). The slope factor showed a reliable relationship with total cover (TCO), total richness of species (TSR) and families (TFR); for altitude this was the case only for the last two variables, but the correlation coefficient was very low. On this basis, slope was chosen as the environmental factor of interest to be analyzed with vegetation. Three clusters of fragments were identified in the classification analysis, for slope as well as for 
Table 5. Results of regression analysis between environmental and vegetation variables of 36 fragments studied in the community of San Nicolás Zoyatlan, Gro. Mexico. STA = statistics, TCO = total cover; TSR $=$ total species richness; TFR = total family richness.

\begin{tabular}{|c|c|c|c|}
\hline STA & TCO & TSR & TFR \\
\hline \multicolumn{4}{|c|}{ Altitude } \\
\hline$R^{2}$ & 0.071 & 13.497 & 15.867 \\
\hline$F$ & 2.612 & 5.305 & 6.412 \\
\hline$p$ & 0.115 & $0.027^{*}$ & $0.016^{*}$ \\
\hline \multicolumn{4}{|c|}{ Lithology } \\
\hline$R^{2}$ & 0.095 & 0.159 & 0.109 \\
\hline$F$ & 0.509 & 0.889 & 0.594 \\
\hline$p$ & 0.796 & 0.516 & 0.732 \\
\hline \multicolumn{4}{|c|}{ Aspect } \\
\hline$R^{2}$ & 0.054 & 0.001 & 0.001 \\
\hline$F$ & 1.929 & 0.002 & 0.005 \\
\hline$p$ & 0.174 & 0.961 & 0.943 \\
\hline \multicolumn{4}{|c|}{ Slope } \\
\hline$R^{2}$ & 27.676 & 31.891 & 30.662 \\
\hline$F$ & 13.010 & 15.920 & 15.035 \\
\hline$p$ & $0.001 *$ & $0.000 *$ & $0.000^{*}$ \\
\hline
\end{tabular}

all vegetation variables (TCO, TSR, TFR); in both cases the ANOVA or MANOVA showed the significant differences between clusters (Table 4).

The differences in the slope clusters are clear: in Cluster-1 ( 9 fragments), the slope values were the lowest ( 2 to $17.6 \%$ ); in Cluster-3 (8 fragments) slopes were the most pronounced (60 to $80 \%$ ); and in Cluster-2 (19 fragments) values were intermediate (30 to $55 \%$ ) (Table 4).

Vegetation variables of Cluster-1 (12 fragments) has the lowest values for TCO (53.37 to $106 \%$ ), TSR (11 to 44 species) and TFR (6 to 14 families). In Cluster-3 (3 fragments) highest values concurred for TCO (207.7 to $304.4 \%$ ), TSR (60 to 93 species) and TFR (28 to 33 families). In Cluster-2 (21 fragments) values for TFR (17 to 26 families) were intermediate compared to the other two clusters (Table 4). Although this trend persisted for TSR and TCO, values similar to those included in the other two clusters occurred in fragments 14, 16 and 33 for the former parameter; and in fragments 7 and 24 for the latter.

(a)

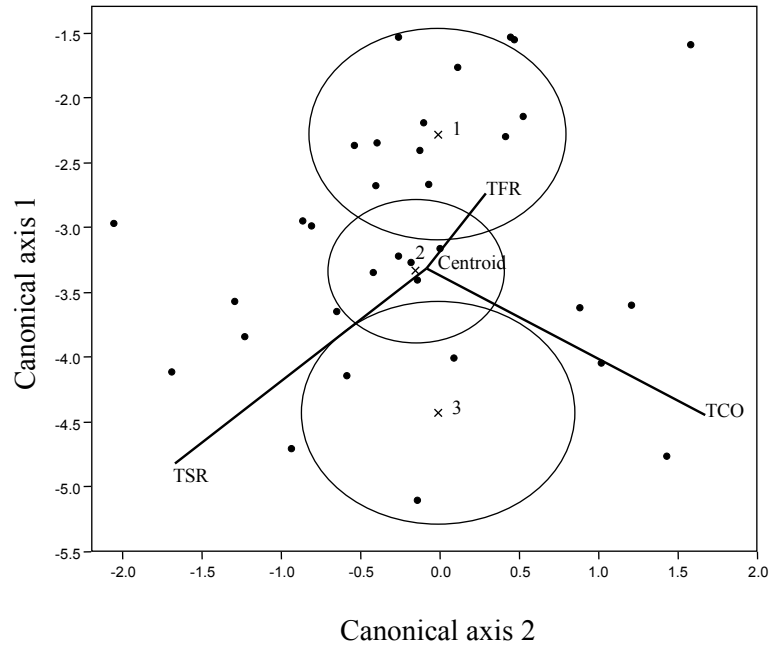

(b)

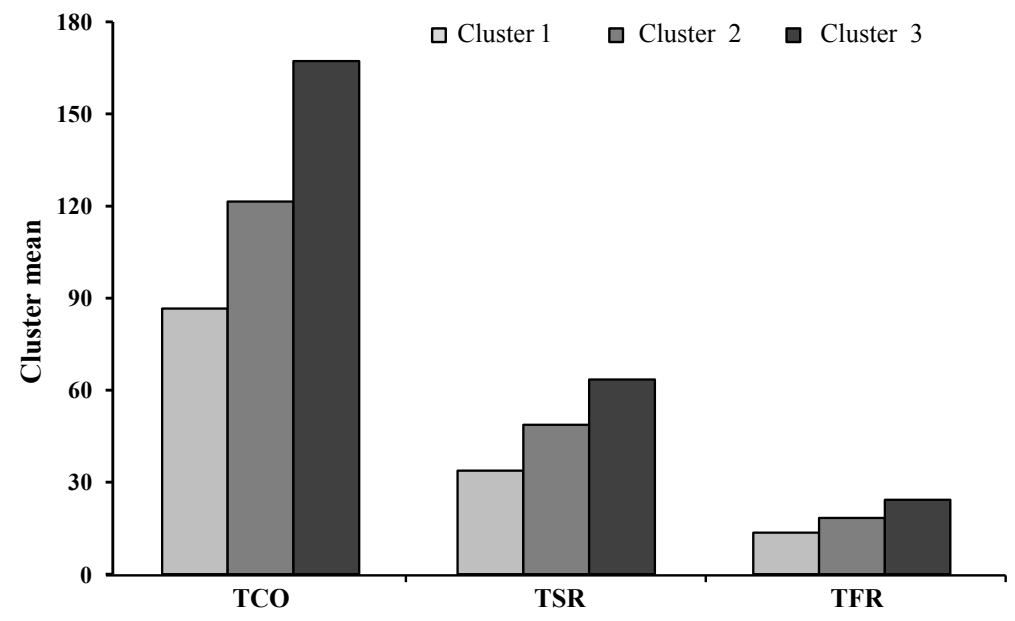

Figure 3. Results of the MANOVA between slope and vegetation variables $(\mathrm{TCO}=$ total cover; $\mathrm{TSR}=$ total species richness and $\mathrm{TFR}=$ total families richness. In (a) clusters formed by the centroid analysis; in (b) cluster means for slope and vegetation variables. 
Clusters obtained from the MANOVA that combined vegetation variables and slope clusters (Table 4) are represented by three centroids (Figure 3a). The first (13 fragments; Table 4) had the cluster mean with lowest values for the slope (range: 2-70 \%), TSR, TFR and TCO (Figure 3b), while centroid-3 (10 fragments) has the highest mean values (slope range: 34-80\%). Intermediate mean values are found in the 12 fragments gathered at the centroid-2 (Figure 3b); it stands out that only the fragments included in centroids 1 and 3 differ statistically (Figure 3a, Table 4).

\section{Discussion}

Vegetation description. Due to insufficient botanical knowledge of Balsas basin (FernándezNava et al. 1998, Jiménez-Ramírez et al. 2003, Pineda-García et al. 2007, Bezaury 2010) and the scarcity of quantitative studies of vegetation structure (Ávila-Sánchez et al. 2010, GuízarNolasco et al. 2010) it is difficult to analyze the floristic data originated from the research in Zoyatlan under the light of other studies. However, in a first approximation we can say that the 236 species determined for Zoyatlan represent $6.28 \%$ of the 4,442 known for the basin (Fernández-Nava et al. 1998). Based on studies about the flora of the mid and high Balsas of the state of Guerrero, we find that our records represent $23.43 \%$ of the total of species known for the TDFs of the municipality of E. Neri, which ranks third in diversity for the whole country (Jiménez-Ramírez et al. 2003); for the zone of Papalutla our data represent 49.27 \% (MartínezGordillo et al. 1997). Considering that this type of vegetation is most common in the Balsas, but also that it stands out for its high species richness and number of endemic species (Rzedowski, 1991b, Bezaury 2010, Rzedowski \& Calderón 2013) these ratios give a good idea of the representativeness of the flora of Zoyatlan; both in relation to what is known for the subregions of the Balsas, as to the context of endemic species. According to Jiménez-Ramírez et al. (2003) and Rodríguez-Jiménez et al. (2005) there are seven species endemic to the TDFs of the Balsas of Guerrero: Acacia bilimekii, Colubrina macrocarpa, Hechtia mooreana, Lasianthaea crocea, L. helianthoides, Opuntia atropes and Rhus nelsonii.

The research area has $29 \%$ of all families registered for Balsas basin (Fernández-Nava et al. 1998) and between 76 and $44 \%$ of those reported in municipalities of the state of Guerrero that are part of the Balsas center (Jiménez-Ramírez et al. 2003, Ávila-Sánchez et al. 2010) and high subregions (Martínez-Gordillo et al. 1997, Guízar-Nolasco et al. 2010). These studies point to Fabaceae, Asteraceae and Poaceae as the richest in species; this is also the case in Zoyatlan. However, while these families gather $48.38 \%$ of the total species, other families represented by $\geq 5$ species were, in order of importance: Euphorbiaceae, Malvaceae, Convolvulaceae, Lamiaceae, Burseraceae, Verbenaceae, Acanthaceae, Boraginaceae and Rubiaceae. All these families, except Lamiaceae, are recognized as the most diverse in dry forests around the world (Gentry 1995, Trejo 1998, Pérez-García et al. 2001, Jiménez-Ramírez et al. 2003, Gallardo-Cruz et al. 2005). Also, although in Zoyatlan were listed $71.43 \%$ of the genera that Rzedowski \& Calderón (2013) stand out as those with the largest number of species in the TDFs of Mexico, only 10 of these genera presented $\geq 4$ species; however, three of them, Dalea, Eupatorium and Salvia, are not included in that study.

The low floristic similarity that occurs between TDFs is a phenomenon described both in terms of different regions of Mexico (Trejo \& Dirzo 2002, Rzedowski \& Calderon 2013) and between "stands" in a micro-basin (Balvanera et al. 2002) or a hill (Gallardo-Cruz et al. 2009). Although those investigations took into account only species that make up the tree stratum, according to our results it is likely that the pattern will recur at different scales regardless of the layer considered. For example, in Zoyatlan $71.67 \%$ of the species were recorded only in the bottom layer and $8.7 \%$ exclusively in the top layer. However, species replacement in the 36 fragments was high because no species was found in all of them and very few (Acacia cochliacantha, Bidens aurea, Bouteloua curtipendula var. caespitosa, Loeselia coerulea and Sanvitalia procumbens) were found in more than $75 \%$. Also, 175 species $(57.95 \%)$ occurred only in 1 to 3 fragments, and of these, $64 \%$ were present only in the bottom layer and $23.4 \%$ were common to both layers. Unfortunately, few comparative inferences can be made because there are very few studies in TDFs that analyze the plant component of the bottom layer (Gallardo-Cruz et al. 2005, Quesada et al. 2009, Sagar et al. 2012). 
Despite the recurrent land use in Zoyatlan for more than five centuries, in its flora we can still recognize trends that are common to TDFs of other areas of the Balsas and the rest of the country; however, five species present in over $75 \%$ of the fragments are known to inhabit disturbed areas (Calderón \& Rzedowski 2001). Four of these five species are part of the most diverse families; while members of Fabaceae are often associated with primary and secondary vegetation, Asteraceae and Poaceae are always related to secondary vegetation (Guízar-Nolazco et al. 2010, López-Sandoval et al. 2010, Rzedowski \& Calderón 2013). In this way composition, richness and species diversity that was found between fragments and the strata of each fragment in Zoyatlan had a great variability. According to the ideas of Halffter \& Moreno (2005) this variability is a typical attribute of secondary vegetation communities.

Vegetation and environmental factors. Despite the variety of environmental conditions of the fragments, only slope showed a positive relation with total richness of species (TSR) and families (TFR) and total cover (TCO). Studies in TDFs from different parts of Mexico, and at different scales, also report a low relationship of species richness and diversity with environmental factors such as altitude, lithology and aspect (Balvanera et al. 2002, Trejo \& Dirzo 2002, Durán et al. 2006, Chaparro-Santiago 2016); however, this has not been the pattern in the case of slope. At both national and local level it has been found that these forests are best preserved in areas with shallow soils and steep slopes, usually $>20^{\circ}$ (Aranguren-Becerra 1994, Trejo \& Dirzo 2000 , 2002). This trend also happens in Zoyatlan, since fragments of lesser slope but with most precarious conditions of all vegetation variables (TSR, TFR and TCO) concur in Cluster-1; on the contrary, Cluster-3 showed the best development of vegetation variables but steepest slopes (Figure 3b; Table 4). This phenomenon is not unique to TDFs; several sources report that areas less altered by human activities are those with less favorable soil, climate and access (Hoonay et al. 1999, Prach et al. 2001, Cousins \& Eriksson 2002, Graae et al. 2003). In Zoyatlan slope influences the availability of land for the development of any productive activity, as well as the choice of the most promising type of use; for example, the intensity of agricultural land use (Cervantes et al. 2005).

Vegetation and intensity of agricultural land use. Analyses of succession in TDFs using chrono sequences point to inconsistencies between the fallow period and the increased complexity of vegetation, both in richness and diversity of species as in the structure. In this regard, some authors (Burgos \& Maass 2004, Hernández-Oria 2007, Lebrija-Trejos et al. 2008, 2010, Álvarez-Yépis et al. 2008) suggest that this is common in places with $\leq 10$ years of fallow. However, over time (usually $>20$ years) the process is "stabilized" because the effect of agricultural use decreases; this is first revealed in the structure and later in the richness and diversity of species. Others (Van der Wal 1999, Kennard 2002, Cramer et al. 2008, Holz et al. 2009) argue that inconsistencies are influenced by the type of agricultural management prior to the abandonment, and by the characteristics of the physical and biotic environment of the fragments (soil conditions, distance to source of propagules, forms of dispersal of species, etc.).

As was indicated four uses derived from variants of semi-intensive agriculture systems were identified in the fragments. These variants played an essential role in the characteristics of vegetation because they alert about differences in vegetation structure of fragments (Table 3), as well as the way clusters result from the classification analysis (Table 4). For example, in Cluster1 fragments are from areas with agriculture use (current and in fallow) and show lowest cluster values for slope and vegetation variables (Figure $3 b$ ). The six fragments with U-1 lacked the top layer, while in those of U-2 that layer was represented by few individuals and usually with heights $\leq 2 \mathrm{~m}$. Furthermore, these fragments had 8 of the 17 species with IVI $\geq 50$ (Table 3 ). In Cluster-3 all the fragments had at least 10 years without agricultural use (U-3 and U-4; Table 4) and matched with the highest mean cluster values (Figure 3b); in their vertical structure, density was well represented both in the range of $\leq 2 \mathrm{~m}$ height, as in the $>2 \mathrm{~m}$ range (Table 3 ).

Perhaps the fragments of Cluster-2, with an intermediate average cluster value not statistically different from the other two (Table 4; Figures $3 \mathrm{a}$ and $\mathrm{b}$ ), represent the inconsistencies regarding time of abandonment of sites and vegetation features, because this cluster includes fragments with three types of uses: from agriculture with residual vegetation (U-2) to nonagricultural use for over 10 years (U-4). Ten species of the top layer with IVI $\geq 50$ were present in these areas, often with individuals of both height layers; however, as expected in U-2, the 
number of individuals was usually lower (Table 3 ). The condition that Cluster-2 is statistically similar to Cluster- 1 and Cluster-3, suggests the evolution of the succession process; it is possible that fragments of Cluster-2 exhibit the extremes of the fallow period. However, the influence of management previous to abandonment should also be taken into account — both in the agricultural process as in residual vegetation - since it's characteristics can help or hinder regeneration (Cramer et al. 2008).

The influence of the intensity of agricultural use was also important in the floristic composition clusters (FCC) derived from K-means analysis. However, it was more evident in the top layer since there were no statistical differences between groups for the bottom layer (table 4). Perhaps the exclusion of species whose presence among fragments was sporadic (1-3 fragments) contributed to this situation because, although this applied to both layers, for the top layer, exclusion of species was only $12.6 \%$ (22) and in the bottom layer it was $64 \%$ (112). Thus, for the top layer Clusters 1 and 3 included almost all fragments (80\%) with more than 10 years without agricultural use and only one with U-3 (Table 4). As in the case of classification analysis, in Cluster- 2 three types of use are present: all fragments with U-2, $90 \%$ of those with U-3 and only $20 \%$ with U-4. These proportions and significant differences in Cluster-2 with respect to Clusters 1 and 3, suggest that FCC of the top layer is a good indicator of the periods of fallow and the succession process.

Regarding the types of agricultural use of fragments and their relationship to 175 infrequent species, it stands out that a significant proportion $(66.9 \%=117$ species $)$ was established in areas with a longer fallow period, U-3 and U-4. The remainder species are distributed almost equally in fragments with shorter fallow periods $(16.6 \% \mathrm{U}-1$ and U-2) and those (16.5\%) that inhabit sites with very different periods of fallow (namely with generalist habits). Surely, the high number of species in fragments with a longer fallow period is related to the development of a canopy that provides good vegetation cover. According to Sagar et al. (2012) cover in TDFs has an important effect on the species composition and diversity of the bottom layer, since it favors higher water retention, a decrease of water stress and an increase in productivity.

The peculiarities of the floristic composition of the fragments indicate that there is a species flow in the landscape of Zoyatlan. Taking into account the fallow periods and the behavior of species that are common to different layers, it turns out that this phenomenon happens when the parent species are present as well as where they are not part of the top layer; this process was evident also in the six fragments that did not have that layer (Appendix 2). In this dynamic 47 species belonging to 17 families were present, although Fabaceae, Asteraceae and Burseraceae were outstanding in providing the highest number of species. The flow that species showed between fragments suggests that the dynamics occur at different levels. On one hand, there are species steadily arriving to the fragments regardless their use type; in some cases even in spite of being represented as adults in only a few fragments. On the other hand, there are species that scarcely enter the fragments although there are adult individuals of them in at least five fragments (preferably in U-2 and U-3); furthermore, there is a minimum income of certain species exclusively in sites with U-4 (Appendix 2).

Negative impacts of fragmentation and chronic disturbance in population and landscape dynamics are diverse and act at different levels (Saunders et al. 1991, Singh 1998, Santos \& Telleria 2006, Fisher \& Lindenmayer 2007). While it might be expected that they could be evident in Zoyatlan due to fragmentation and chronic disturbance over more than five centuries, this was not conclusive because there are still many features in the vegetation that characterize the TDFs of the Balsas basin. The dynamics of vegetation regeneration, which has its best expression in fragments less suitable for the development of agriculture due to their inaccessibility was also evident; this suggests that agriculture and grazing has not exceed the threshold that would prevent the dynamics and reorganization of the socio-ecological system (Lunt \& Spooner 2005, Cramer \& Hobbs 2007). According to land use in 1998 (Cervantes et al. 2014) and the results of this research, the fragments with U-2, U-3 and U-4 are represented in nearly 600 ha. While this highlights the importance of the process at a landscape scale, the largest area occupied by shrubs and short trees (478 ha), suggests an impoverishment of the structure and composition of vegetation. However, the difference in the movement of species between fragments, points to species whose colonization habits lead the succession process, e.g., species of the genus Acacia, 
as well as those with specific requirements (U-3 and U-4) to ensure their establishment and development, e.g., species of the genus Lysiloma. All this is very useful for choosing species with the highest potential for environmental restoration actions; this was, in fact, the basic information for the establishment of plantations and agroforestry systems (Cervantes et al. 2001) that currently have successful results in Zoyatlan (Cervantes et al. 2014).

\section{Acknowledgments}

We are grateful to Claudia Hernández Díaz for her help in herbarium activities, as well as Beatriz Castillo Avila and Alan Chaparro Santiago for their assistance in the systematization of databases. We are indebted to the people of San Nicolás Zoyatlan for their invaluable and continuous assistance.

\section{Literature cited}

Afifi A, Clark V. 1997. Computer-Aided Multivariate Analysis. Chapman \& Hall/CRC, Washington, D.C. DOI: 10.1002/bimj.4710390716

Álvarez-Yépiz JC, Martínez-Yrízar A, Búrquez A, Lindquist C. 2008. Variation in vegetation structure and soil properties related to land use history of old-growth and secondary tropical dry forest in northwestern Mexico. Forest Ecology and Management 256: 355-366. DOI: 10.1016/j.foreco.2008.04.049

Aranguren-Becerra AR. 1994. Caracterización de los bosques tropicales caducifolios y del aprovechamiento de sus recursos por comunidades nahuas de la Montaña de Guerrero. MSc Thesis. Universidad Nacional Autónoma de México. 121.

Argueta A. 1994. Atlas de las Plantas de la Medicina Tradicional Mexicana I, II, III. México: Instituto Nacional Indigenista.

Ávila-Sánchez P, Sánchez-González A, Catalán-Everástico C. 2010. Estructura y composición de la vegetación del Cañón del Zopilote, Guerrero, México. Revista Chapingo Serie Ciencias Forestales y del Ambiente 16: 119-138.

Balvanera P, Lott E, Segura G, Siebe C, Islas A. 2002. Patterns of $\beta$-diversity in a Mexican tropical dry forest. Journal of Vegetation Science 13:145-158. DOI: 10.1111/j.1654-1103.2002.tb02034.x

Bezaury J. 2010. Las selvas secas del Pacífico Mexicano en el contexto mundial. In: Ceballos G, Martínez L, García A, Espinoza E, Bezaury J, Dirzo R. eds. Diversidad, Amenazas y Áreas Prioritarias para la Conservación de las Selvas Secas del Pacífico de México. Fondo de Cultura Económica. 21-40.

Burgos A, Maass JM. 2004. Vegetation change associated with land-use in tropical dry forest

areas of Western Mexico. Agriculture, Ecosystems and Environment 104: 475-481. DOI: 10.1016/ j.agee.2004.01.038

Calderón G, Rzedowski J. 2001. Flora fanerogámica del valle de México. Michoacán. Instituto de Ecología, A.C. y CONABIO.

Casas A, Viveros JL, Caballero J. 1994. Etnobotánica mixteca: Sociedad, Cultura y Recursos Naturales en la Montaña de Guerrero. México. Instituto Nacional Indigenista CONACULTA.

Cervantes V, López-González M, Salas-Nava N, Hernández-Cárdenas G. 2001. Técnicas para Propagar Especies Nativas de Selva Baja Caducifolia y Criterios para Establecer Áreas de Reforestación. México. PRONARE-SEMARNAP-Facultad de Ciencias UNAM.

Cervantes V, De Teresa AP. 2004. Historia del uso del suelo en la comunidad de San Nicolás Zoyatlán, Guerrero. Alteridades 14: 57-87.

Cervantes V, Gama-Castro JE, Hernández-Cárdenas G, Meave del Castillo J. 2005. The land classification system of the San Nicolás Zoyatlan (S Mexico) nahuatl indigenous community: a basis for a suitable parametric soil use proposal. Research in Human Ecology Review 12: 44-58.

Cervantes V, Gama-Castro JE, Roldán-Aragón IE, Hernández-Cárdenas G. 2014. Basis for implementing restoration strategies: San Nicolás Zoyatlan social-ecological system (Guerrero, México). Terra Latinoamericana 32: 143-159.

Challenger A. 1998. Utilización y Conservación de los Ecosistemas Terrestres de México: Pasado, Presente y Futuro. México. Instituto de Biología UNAM-Agrupación Sierra Madre SC.

Chaparro-Santiago A. 2016. Evaluación de la estrategia de restauración ambiental (rehabilitación) establecida en la comunidad rural Villa de Guadalupe, Municipio de Tlapa de Comonfort, Guerrero. MSc. Thesis. Universidad Autónoma Metropolitana.

Cramer VA, Hobbs RJ. 2007. Old Fields: Dynamics and Restoration of Abandoned Farmland. Island Press, Washington D.C.

Cramer VA, Hobbs RJ, Standish RJ. 2008. What's new about old fields? Land abandonment and ecosystem assembly. Trends in Ecology \& Evolution 23: 104-112. DOI: 10.1016/j.tree.2007.10.005 
Cousins SAO, Eriksson O. 2002. The influence of management history and habitat on plant species richness in a rural hemiboreal landscape, Sweden. Landscape Ecology 17: 517-529. DOI: 10.1023/ A:1021400513256

Dorado O, Arias DM, Alonso G, Maldonado B. 2002. Educación ambiental para la biodiversidad en el trópico seco, reserva de la biosfera Sierra de Huautla, Morelos, México. Tópicos en Educación Ambiental 4: 23-33.

Durán E, Meave JA, Lott EJ, Segura G. 2006. Structure and tree diversity patterns at the landscape level in a Mexican tropical deciduous forest. Boletín de la Sociedad Botánica de México 79: 43-60.

Everitt BS, Dunn G. 1991. Applied Multivariate Data Analysis. New York. Wiley.

Fernández-Nava R, Rodríguez-Jiménez C, Arreguín-Sánchez ML, Rodríguez-Jiménez A. 1998. Listado florístico de la cuenca del río Balsas, México. Polibotánica 9: 1-151.

Fischer J, Lindenmayer DB. 2007. Landscape modification and habitat fragmentation: a synthesis. Global Ecology and Biogeography 16: 265-280. DOI: 10.1111/j.1466-8238.2007.00287.x

Gallardo-Cruz JA, Meave JA, Pérez-García EA. 2005. Estructura, composición y diversidad de la selva baja caducifolia del Cerro Verde, Nizanda (Oaxaca), México. Boletín de la Sociedad Botánica de México 76: 19-35.

Gallardo-Cruz JA, Pérez-García EA, Meave JA. 2009. $\beta$-Diversity and vegetation structure as influenced by slope aspect and altitude in a seasonally dry tropical landscape. Landscape Ecology 24: 273-482. DOI: $10.1007 / \mathrm{s} 10980-009-9332-1$

García E. 1988. Modificaciones al Sistema de Clasificación de Köppen. México. Instituto de Geografía, UNAM.

Gentry AH. 1995. Diversity and floristic composition of neotropical dry forest. In: Bullock SH, Mooney HA, Medina E. eds. Seasonally Dry Tropical Forest, Cambridge University Press 146-194. DOI: 10.1017/CBO9780511753398

Graae BJ, Sunde PB, Fritzboger B. 2003.Vegetation and soil differences in ancient opposed to new forests. Forest Ecology and Management 177: 179-190. DOI: 10.1016/S0378-1127(02)00438-3

Guízar-Nolazco E, Granados-Sánchez D, Castañeda-Mendoza A. 2010. Flora y vegetación en la porción sur de la mixteca poblana. Revista Chapingo Serie Ciencias Forestales y del Ambiente 16: 95-118.

Halffter G, Moreno CE. 2005. Significado biológico de las diversidades alfa, beta y gama. In: Halffter G., Soberón J., Koleff P. y Melic A. eds. Sobre Diversidad biológica: el significado de las diversidades alfa, beta y gamma, México: CONABIO, 5-18.

Hernández-Oria JG. 2007. Desaparición del bosque seco en el bajío mexicano: implicaciones del ensamblaje de especies y grupos funcionales en la dinámica de una vegetación amenazada. Zonas Áridas 11: 13-31.

Hernández-XE. 1998. Aspectos de la domesticación de plantas en México: una apreciación personal. In: Ramamoorthy T, Bye R, Lot A, Fa J. eds. Diversidad Biológica de México: Orígenes y Distribución. México: Instituto de Biología, UNAM, 715-738.

Holz S, Placci G, Quintana RD. 2009. Effects of history of use on secondary forest regeneration in the Upper Parana Atlantic Forest (Misiones, Argentina). Forest Ecology and Management 258: 1629-1642. DOI: $10.1016 /$ j.foreco.2009.07.023

Hoonay O, Hermy M, Coopin P. 1999. Impact of habitat quality on forest plant species colonization. Forest Ecology and Management 115: 239-246. DOI: 10.1016/S0378-1127(98)00396-X

Janzen DH, 1988. Management of hábitat fragments in a tropical dry forest: growth. Annals of the Missouri Botanical Garden 75:105-116. DOI: $10.2307 / 2399468$

Jiménez-Ramírez J, Martínez-Gordillo JM, Valencia-Ávalos S, Cruz-Durán R, Contreras-Jiménez JL, Moreno-Gutiérrez E, Calónico-Soto J. 2003. Estudio florístico del Municipio Eduardo Neri, Guerrero. Anales del Instituto de Biología, Serie Botánica 74:79-142.

Johnson D. 2000. Métodos Multivariados Aplicados al Análisis de Datos. México: International Thomson Editores.

Kennard DK. 2002. Secondary forest succession in a tropical dry forest: patterns of development across a 50-year chronosequence in lowland Bolivia. Journal of Tropical Ecology 18: 53-65. DOI: 10.1017/ S0266467402002031

Lebrija-Trejos E, Bongers F, Pérez-García EA. Meave JA. 2008. Succesional change and resilience of a very dry tropical deciduous forest following shifting agricultura. Biotropica 40: 422-431. DOI: 10.1111/ j.1744-7429.2008.00398.x

Lebrija-Trejos E, Meave JA, Poorter L, Pérez-García EA, Bongers F. 2010. Pathways, mechanisms and predictability of vegetation change during tropical dry forest succession. Perspectives in Plant Ecology, Evolution and Systematics 12: 267-275. DOI: 10.1016/j.ppees.2010.09.002

López-Sandoval JA, Koch SD, Vázquez-García LM, Munguía-Lino G, Morales-Rosales EJ. 2010. Estudio florístico de la parte central de la barranca Nenetzingo, Municipio de Ixtapan de la Sal, Estado de México. Polibotánica 30: 9-33. 
Lott EJ, Bullock SH, Solís-Magallanes A. 1987. Floristic Diversity and Strutcure of Upland and Arroyo forest of Coastal Jalisco. Biotropica 19: 228-235. DOI: $10.2307 / 2388340$

Lunt ID, Spooner PG. 2005. Using historical ecology to understand patterns of biodiversity in fragmented agricultural landscapes. Journal of Biogeography 32: 1859-1873. DOI: 10.1111/j.13652699.2005.01296.x

Maass JM, Balvanera P, Castillo A, Daily GC, Mooney HA, Ehrlich P, Quesada M, Miranda A, Jaramillo VJ, Garcia-Oliva F, Martinez-Yrizar A, Cotler H, Lopez-Blanco J, Perez-Jimenez A, Búrquez A, Tinoco C, Ceballos G, Barraza L, Ayala R, Sarukhán J. 2005. Ecosystem services of tropical dry forests: insights from long-term ecological and social research on the Pacific Coast of Mexico. Ecology and Society 10: 17.

Maass M, Búrquez A, Trejo I, Valenzuela D, González M, Rodríguez M, Arias H. 2010. Amenazas. In: Ceballos G, Martínez L, García A, Espinoza E, Bezaury J, Dirzo R. eds. Diversidad, Amenazas y Áreas Prioritarias para la Conservación de las Selvas Secas del Pacífico de México. México: Fondo de Cultura Económica. 21-40.

Martínez-Gordillo M, Valencia-Ávalos S, Calónico-Soto J. 1997. Flora de Papalutla, Guerrero y de sus alrededores. Anales del Instituto de Biología Universidad Nacional Autónoma de México, Serie Botánica 68: $107-133$.

Matteucci SD, Colma A. 1982. Metodología para el estudio de la vegetación. Washington, D.C. Organización de los Estados Americanos.

Miles L, Newton AC, DeFries RS, Ravilious C, May I, Blyth S, Kapos V, Gordon JE. 2006. A global overview of the conservation status of tropical dry forest. Journal of Biogeography 33: 491-505. DOI: $10.1111 / \mathrm{j} .1365-2699.2005 .01424 . \mathrm{x}$

Montgomery D. 1991. Diseño y Análisis de Experimentos. México D.F. Grupo Editorial Iberoamérica.

Mueller-Dombois D, Ellenberg H. 1974. Aims and Methods of Vegetation Ecology. New York: John Wiley \& Sons.

Murphy PG, Lugo AE. 1986. Ecology of tropical dry forest. Annual Review of Ecology and Systematics 17: 67-88. DOI: 10.1146/annurev.es.17.110186.000435

Newton AC, Tejedor N. 2011. Principles and Practice of Forest Landscape Restoration. Case Studies from the Drylands of Latin America. Switzerland: IUCN. 1-22.

Noguera FA, Vega-Rivera JH, García-Aldrete AN, Quesada-Avendaño M. 2002. Historia Natural de Chamela. Instituto de Biología, Universidad Nacional Autónoma de México.

Pérez-García EA, Meave J, Gallardo C. 2001. Vegetación y flora de la región de Nizanda, Istmo de Tehuantepec Oaxaca, México. Acta Botánica Mexicana 56: 19-88.

Pineda-García F, Arredondo-Amezcua L, Ibarra-Manríquez G. 2007. Riqueza y diversidad de especies leñosas del bosque tropical caducifolio El Tarimo, Cuenca del Balsas, Guerrero. Revista Mexicana de Biodiversidad 78: 129-139.

Prach K., Pysek P. and Basti M. 2001. Spontaneus vegetation succession in human-disturbed habitats: a pattern across seres. Applied Vegetation Science 4: 83-88. DOI: 10.1111/j.1654-109X.2001.tb00237.x

Quesada M, Sanchez-Azofeifa GA, Alvarez-Añorve M, Stoner KE, Avila-Cabadilla L, Calvo-Alvarado J, Castillo A, Espírito-Santo MM, Fagundes M, Fernandes GW, Gamon J, Lopezaraiza-Mikel M, Lawrence D, Cerdeira-Morellato LP, Powers JS, Neves FS, Rosas-Guerrero V, Sayago R, Sanchez-Montoya G. 2009. Succession and management of tropical dry forest in the Americas: review and new perspectives. Forest Ecology and Management 258: 1014-1024. DOI: 10.1016/j.foreco.2009.06.023

Rodríguez-Jiménez C, Fernández-Nava R, Arreguín-Sánchez M, Rodríguez-Jiménez A. 2005. Plantas vasculares endémicas de la Cuenca del Río balsas, México. Polibotánica 20: 73-99.

Rzedowski J, Calderón G. 1987. El bosque tropical caducifolio en la región mexicana del Bajío. Trace 12: $12-21$.

Rzedowski J. 1991a. Diversidad y orígenes de la flora fanerogámica de México. Acta Botánica Mexicana 14: $3-21$.

Rzedowski J. 1991b. El endemismo en la flora fanerogámica mexicana: una apreciación analítica preliminar. Acta Botánica Mexicana. 15: 47-64.

Rzedowski J, Calderón G. 2013. Datos para la apreciación de la flora fanerogámica del Bosque Tropical Caducifolio de México. Acta Botánica Mexicana 102: 1-23.

Sagar R, Pandey A, Singh JS. 2012. Composition, species diversity, and biomass of the herbaceous community in dry tropical forest of northern India in relation to soil moisture and light intensity. The Environmentalist 32: 485-493. DOI: 10.1007/s10669-012-9414-5

Santos T, Tellería JL. 2006. Pérdida y fragmentación del hábitat: efecto sobre la conservación de las especies. Ecosistemas 15: 3-12.

SAS. 1989. JMP User's Guide. Version 2 of JMP. SAS. Cary, Institute Inc.

Saunders D, Hobbs RJ, Margules CR.1991. Biological consequences of ecosystem fragmentation: a review. Conservation Biology 5: 18-32. 
Received:

December 2nd, 2016

Accepted:

December 16th, 2016
Singh SP. 1998. Chronic disturbance, a principal cause of environmental degradation in developing countries. Environmental Conservation 25: 1-2.

Soto JC. 2010. Plantas útiles de la cuenca del Balsas. In: Ceballos G, Martínez L, García A., Espinoza E, Bezaury J, Dirzo R. eds. Diversidad, Amenazas y Áreas Prioritarias para la Conservación de las Selvas Secas del Pacífico de México. Fondo de Cultura Económica.

Toledo VM, Carabias J, Toledo C, González-Pacheco C. 1989. La producción rural en México: alternativas ecológicas. Fundación Universo Veintiuno.

Toledo VM, Ordóñez M. 1998. El panorama de la biodiversidad de México: una revisión de los hábitats terrestres. In: Ramamoorthy T, Bye R, Lot A, Fa J. eds. Diversidad Biológica de México: Orígenes y Distribución. México: UNAM Instituto de Biología, 739-758.

Trejo I. 1998. Distribución y diversidad de selvas bajas de México: relación con el clima y el suelo. $\mathrm{PhD}$ Thesis. Facultad de Ciencias, UNAM.

Trejo I, Dirzo R. 2000. Deforestation of seasonally dry tropical forest: A national and local analysis in Mexico. Biological Conservation 94: 133-142. DOI: 10.1016/S0006-3207(99)00188-3

Trejo I, Dirzo R. 2002. Floristic diversity of Mexican seasonally tropical forest. Biodiversity and Conservation 11: 2063-2084. DOI: 10.1023/A:1020876316013

Trejo I. 2010. Las selvas secas del pacífico mexicano. In: Ceballos G, Martínez L, García A, Espinoza E, Bezaury J, Dirzo R. eds. Diversidad, Amenazas y Áreas Prioritarias para la Conservación de las Selvas Secas del Pacífico de México, Fondo de Cultura Económica, 41-53.

UNDP 2004. Sharing innovative experiences. Examples of the successful conservation and sustainable use of dryland biodiversity. <http://ssc.undp.org/content/ssc/library/solutions/partners/gssdAcademy/ Volume_9_Examples_of_Successful_Conservation_and_Sustainable_use_of_Biodiversity.html $>$ (accessed 3 dec, 2015).

Van der Wal H. 1999. Chinantec Shifting Cultivation: Interactive Landuse. A case-study in the Chinantla, México, on Secondary Vegetation, Soils and Crop Performance under Indigenous Shifting Cultivation. Netherlands: Treemail Publishers.

Vega C. 1991. Códice Azoyú 1. El Reyno de Tlalchinollan. México: Fondo de Cultura Económica. 
Appendix 1. Plant species list of the agrarian community of San Nicolás Zoyatlan, Gro. Mexico. F1S = family with only one species; FER = number of fragments in which the species was re-corded; $\mathrm{ETB}=$ species found in top and bottom layers; $\mathrm{ETL}=$ species found only in the top layer; GK = group(s) to which the species belong according to the K-means analysis for the bottom (B) and top (T) layer.

\begin{tabular}{|c|c|c|c|c|c|c|}
\hline TAXON & F1S & FER & ETB & ETL & GKB & GKT \\
\hline \multicolumn{7}{|l|}{ PTERIDOPHYTA } \\
\hline \multicolumn{7}{|l|}{ LYCOPODIOPSIDA } \\
\hline \multicolumn{7}{|l|}{ SELAGINELLACEAE } \\
\hline Selaginella P. Beauv. sp. & $X$ & 12 & & & $1,2,3$ & \\
\hline \multicolumn{7}{|l|}{ POLYPODIOPSIDA } \\
\hline \multicolumn{7}{|l|}{ ANEMIACEAE } \\
\hline Anemia adiantifolia (L.) Sw. & $x$ & 2 & & & & \\
\hline \multicolumn{7}{|l|}{ PTERIDACEAE } \\
\hline Cheilanthes skinneri (Hook.) R.M.Tryon \& A.F.Tryon & & 1 & & & & \\
\hline Cheiloplecton rigidum (Sw.) Fée & & 1 & & & & \\
\hline Pellaea oaxacana Mickel \& Beitel & & 8 & & & 1,3 & \\
\hline \multicolumn{7}{|l|}{ PINOPHYTA } \\
\hline \multicolumn{7}{|l|}{ PINOPSIDA } \\
\hline \multicolumn{7}{|l|}{ CUPRESSACEAE } \\
\hline Juniperus flaccida Schltdl. & $x$ & 10 & $x$ & & 1,2 & $1,2,3$ \\
\hline \multicolumn{7}{|l|}{$\begin{array}{l}\text { MAGNOLIOPHYTA } \\
\text { LILIOPSIDA }\end{array}$} \\
\hline \multicolumn{7}{|l|}{ ARECACEAE } \\
\hline Brahea dulcis (Kunth) Mart. & $x$ & 4 & & $X$ & & $1,2,3$ \\
\hline \multicolumn{7}{|l|}{ ASPARAGACEAE } \\
\hline Agave kirchneriana A. Berger & & 7 & & $x$ & & $1,2,3$ \\
\hline Agave tequilana F.A.C. Weber & & 2 & & $x$ & & \\
\hline Smilacina Desf. sp. & & 1 & & & & \\
\hline \multicolumn{7}{|l|}{ BROMELIACEAE } \\
\hline Hechtia mooreana L.B. Sm. & $X$ & 3 & $X$ & & & \\
\hline \multicolumn{7}{|l|}{ COMMELINACEAE } \\
\hline Commelina L. sp. & & 1 & & & & \\
\hline sp. 1 & & 1 & & & & \\
\hline sp. 2 & & 1 & & & & \\
\hline sp. 3 & & 3 & & & & \\
\hline \multicolumn{7}{|l|}{ CYPERACEAE } \\
\hline Cyperus hermaphroditus Standl. & $X$ & 1 & & & & \\
\hline \multicolumn{7}{|l|}{ DIOSCOREACEAE } \\
\hline Dioscorea L. sp 1. & & 1 & & & & \\
\hline Dioscorea L. sp 2. & & 6 & & & $1,2,3$ & \\
\hline \multicolumn{7}{|l|}{ IRIDACEAE } \\
\hline Cipura Aubl. sp. & & 1 & & & & \\
\hline Sessilanthera citrina Cruden & & 1 & & & & \\
\hline Tigridia Juss. sp. & & 1 & & & & \\
\hline \multicolumn{7}{|l|}{ LILIACEAE } \\
\hline sp. 1 & $x$ & 2 & & & & \\
\hline \multicolumn{7}{|l|}{ ORCHIDACEAE } \\
\hline Bletia Ruiz \& Pav. sp. & & 5 & & & 1,3 & \\
\hline Malaxis urbana E.W. Greenw. & & 2 & & & & \\
\hline \multicolumn{7}{|l|}{ POACEAE } \\
\hline Andropogon gerardi Vitman & & 2 & & & & \\
\hline Andropogon hirtifolius J. Presl & & 8 & & & 1,2 & \\
\hline Aristida gentilis Henrard & & 8 & & & $1,2,3$ & \\
\hline
\end{tabular}


Appendix 1. Continuation.

\section{TAXON}

F1S

FER ETB ETL GKB GKT

Aristida hitchcockiana Henrard

Aristida ternipes Cav.

Bouteloua curtipendula var. caespitosa Gould \& Kapadia

Bouteloua diversispicula Columbus

Bouteloua repens (Kunth) Scribn. \& Merr.

Cenchrus longispinus (Hack. Ex Kneuch.) Fernald

Chloris virgata Sw.

Eragrostis hypnoides (Lam.) Britton, Sterns \& Poggenb.

Eriochloa nelsonii Scribn. \& J.G. Sm

Hackelochloa granularis (L.) Kuntze

Ichnanthus P. Beauv. sp.

Lasiacis grisebachii Hitchc.

Melinis repens (Willd.) Zizka

Oplismenus burmannii (Retz.) P. Beauv.

Paspalum conjugatum P.J. Bergius

Paspalum convexum Flüggé

Setaria geniculata P. Beauv.

Setaria lutescens (Stuntz) F.T. Hubb.

Setaria parviflora (Poir.) Kerguélen

Trachypogon secundus (J. Presl) Scribn. MAGNOLIOPSIDA

\section{ACANTHACEAE}

Carlowrightia arizonica A. Gray

Dicliptera thlaspioides Nees

Dyschoriste ovata (Cav.) Kuntze

Elytraria bromoides Oerst.

Ruellia hookeriana Hemsl.

sp. 1

Tetramerium nervosum Nees

\section{AMARANTHACEAE}

Gomphrena globosa L.

ANACARDIACEAE

Comocladia mollissima Kunth

Pseudosmodingium Engl. sp.

Rhus galeotti Standl.

Rhus nelsonii F.A. Barkley

ANNONACEAE

Annona L. sp.

APIACEAE

sp. 1

APOCYNACEAE

Gonolobus grandiflorus (Cav.) R. Br. ex Schult.

Haplophyton cinereum Woodson

Marsdenia lanata (Paul G. Wilson) W.D. Stevens

Thevetia thevetioides (Kunth) K. Schum.

sp. 1

\section{ARISTOLOCHIACEAE}

Aristolochia mycteria Pfeifer

Aristolochia orbicularis Duch.

ASCLEPIADACEAE

\section{1}

17

32

7

18

8

2

4

1

3

2

3

12

3

1

1

3

5

4

3

1

1,2
1,3

1,3

$1,2,3$

1

1,2

1,3

$\begin{array}{ll}x & 2\end{array}$

1

4
2

$x$

x 2

$x$

$2 \quad x$

1

x

3

1

3

3

2

X

sp. 1

$\begin{array}{lll}X & 1 & X\end{array}$ 
Appendix 1. Continuation.

TAXON

F1S

FER ETB ETL GKB GKT

ASTERACEAE

Acourtia dugesii (A. Gray) Reveal \& R.M. King

Ageratina tomentella (Scharad) R.M. King \& H. Rob

Ageratum corymbosum Zuccagni

Aldama dentata La Llave.

Baccharis multiflora Kunth

Barroetea subuligera (S. Schauer) A. Gray

Bidens aurea (Aiton) Sherff

Bidens lemmonii A. Gray

Brickellia cardiophylla B.L. Rob.

Brickellia tomentella A. Gray

Brickellia veronicifolia (Kunth) A. Gray

Calea hypoleuca B.L. Rob. \& Greenm.

Cosmos sulphureus Cav.

Dyssodia porophyllum (Cav.) Cav. var. cancellata

(Cass.) Strother

Dyssodia tagetiflora Lag.

Eupatorium calophyllum (Greene) B.L. Rob.

Eupatorium odoratum L.

Eupatorium ovaliflorum Hook. \& Arn.

Eupatorium L. sp 1

Eupatorium L. sp 2

Hieracium L. sp.

Lasianthaea crocea (A. Gray) K.M. Becker

Lasianthaea helianthoides DC.

Melampodium americanum L.

Melampodium divaricatum DC.

Melampodium paniculatum Gardner

Milleria quinqueflora L.

Otopappus imbricatus S.F. Blake

Pectis prostrata Cav.

Perymenium mendezii DC. var. verbesinoides

(DC.) J.J. Fay

Pinaropappus roseus Less.

Porophyllum lindenii Sch. Bip.

Porophyllum punctatum S.F. Blake

Porophyllum tagetoides DC.

Sanvitalia procumbens Lam.

Senecio hederaefolius Hemsl.

Senecio L. sp.

Simsia amplexicaulis Pers.

Simsia foetida S.F. Blake

Stevia micrantha Lag.

Stevia ovata Willd

Stevia subpubescens Lag.

Tagetes Iunulata Ortega

Taraxacum officinale F.H. Wigg.

Tridax mexicana A.M. Powell

2

8

$x$

$1,2 \quad 1,2,3$

11

11

11

29

2

1

1

2

6

14

7

$x$

1,2

$x$

$1,2,3$

$1,2,3$

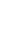

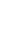

$1,2,3$

1,2

26

1

1

1

1

2

2

3

7

1

1

12

17

1

3

1

2

$\mathrm{X}$

$1,2,3$

1,2

$x$

$x$

X

X

X

X

$1,2,3$

$1,2,3$

x

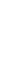

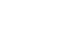

X

2

2

34 
Appendix 1. Continuation.

\section{TAXON}

F1S

FER

Vernonia salicifolia Less.

Viguiera dentata (Cav.) Spreng.

Viguiera oaxacana S.F. Blake

Wedelia acapulcensis Kunth

Zaluzania pringlei Greenm.

Zinnia peruviana L.

Zinnia violacea Cav.

sp. 1

BIGNONIACEAE

Tecoma stans (L.) Kunth

BORAGINACEAE

Bourreria ovata Miers

Cordia curassavica (Jacq.) Roem. \&

Schult. Lennoa Lex. sp.

Lithospermum L. sp.

Nama L. sp.

sp. 1

Tournefortia hirsutissima L.

\section{BURSERACEAE}

Bursera ariensis (Kunth) McVaugh \&

Rzed. Bursera bipinnata Engl.

Bursera copallifera (Sessé \& Moc.) Bullock

Bursera glabrifolia Engl.

Bursera longipes Standl.

Bursera mirandae C.A. Toledo

Bursera morelensis Ramírez

CACTACEAE

Mammillaria Haw. sp.

Opuntia atropes Rose

Opuntia pumila Rose

CANNABACEAE

Celtis iguanaea (Jacq.) Sarg.

CAPRIFOLIACEAE

Valeriana L. sp.

CARYOPHYLLACEAE

Drymaria tenuis S. Watson

CONVOLVULACEAE

Ipomoea hederifolia L.

Quamoclit coccinea Moench

Evolvulus alsinoides $\mathrm{L}$.

Ipomoea arborescens (Humb. \& Bonpl. ex

Willd.) G. Don

Ipomoea capillacea G. Don

Ipomoea murucoides Roem. \& Schult.

Ipomoea L. sp. 1

Ipomoea L. sp. 2

sp. 1

sp. 2

\section{CUCURBITACEAE}

sp. 1

4

7

7

2

2

3

7

6

1

X

22

X

$1,2,3 \quad 1,2,3$

1,3

1

$X$
$X \quad 1,2,3$

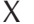

X

X 22

$\begin{array}{cccc}6 & X & & 1,2,3 \\ 7 & X & 1,3 & 2 \\ 1 & & \end{array}$

1

1

2

$1 \quad x$

$21 \quad x$

$1,2,3 \quad 1,2$

X

$1,3 \quad 1,2,3$

$1,2,3 \quad 1,2,3$

$1,2,3$

$X$

X

2

3

13

12

$1,3 \quad 1,2,3$

$1,2,3$

X 1

X

X 1

X 6

1,2

2

1

7

24

X

1,2

$1,2,3 \quad 1,2,3$

17

1

2

1

1

1

X
$1,2,3$ 
Appendix 1. Continuation.

$$
\text { TAXON }
$$

F1S

FER ETB ETL GKB GKT

\section{ERYTHROXILACEAE}

Eythroxylum rotundifolium Lunan

\section{EUPHORBIACEAE}

Acalypha indica L.

Acalypha L. sp.

Acalypha subviscidaS. Watson

Croton ciliatoglandulifer Ortega

Ditaxis Vahl ex A. Juss. sp.

Euphorbia cumbrae Boiss

Euphorbia cyathophora Murray

Euphorbia dioscoreoides Boiss

Euphorbia heterophylla L.

Euphorbia hirta L.

Euphorbia ocymoidea L.

Euphorbia prostrata Aiton

Euphorbia L. sp.

Tragia nepetifolia Cav.

FABACEAE

Acacia bilimekii J.F. Macbr.

Acacia cochliacantha Humb. \& Bonpl. ex Willd.

Acacia farnesiana (L.) Willd.

Acacia pennatula (Schltdl. \& Cham.) Benth.

Aeschynomene americana $\mathrm{L}$.

Brongniartia podalyrioides Kunth

Brongniartia Kunth sp.

Calliandra houstoniana (Mill.) Standl.

Calopogonium mucunoides Desv.

Calopogonium Desv. sp.

Chamaecrista absus (L.) H.S. Irwin \& Barneby

Chamaecrista nictitans Moench

Coursetia caribaea (Jacq.) Lavin

Crotalaria filifolia Rose

Crotalaria pumila Ortega

Crotalaria sagittalis $\mathrm{L}$.

Dalea foliolosa (Aiton) Barneby var. citrina

(Rydb.) Barneby

Dalea hegewischiana Steud.

Dalea humilis G. Don

Dalea tomentosa var. psoraleoides (Moric.) Barneby

Desmodium procumbens var. transversum

(B.L. Rob. \& Greenm.) B.G. Schub.

Desmodium sericophyllum Schltdl.

Desmodium Desv. sp.

Desmodium tortuosum (Sw.) DC.

Eysenhardtia polystachya (Ortega) Sarg.

Galactia discolor Donn. Sm.

X

\section{1}

10

1

2

19

3

15

15

2

15

8

12

24

4

10

22

29

12

17

4

2

1

6

1

1

1

8

3

13

5

3

6

Galactia P. Browne sp.

Galactia viridiflora Standl.

Havardia acatlensis (Benth.) Britton \& Rose

Indigofera jamaicensis Spreng.

Indigofera platycarpa Rose
$1,2,3$

$1,2,3$

1,3

$1,2,3$

$1,2,3$

1

$1,2,3$

$1,2,3$

1,2

1,2

$1,2,3 \quad 1,2,3$

$1,2,3 \quad 1,2,3$

1,2

$11,2,3$

1

$1,2 \quad 1,2,3$

X

$1,2 \quad 1,2,3$

$1,2,3$

X

$1,2,3$

1,2

1

1,2

1,2

1,2

1,2

X

1,2

X

$1,2,3$

1,2

1 
Appendix 1. Continuation.

\section{TAXON}

F1S FER

Indigofera L. sp.

Lonchocarpus Kunth sp.

Lupinus mexicanus Cerv.

Lysiloma acapulcense (Kunth) Benth.

Lysiloma divaricatum (Jacq.) Benth.

Macroptilium atropurpureum (L.) Urb.

Macroptilium gibbosifolium (Ortega) A. Delgado

Marina greenmaniana (Rose) Barneby var.

muelleri Barneby

Marina minutiflora (Rose) Barneby

Marina scopa Barneby

Marina spiciformis (Rose) Barneby

Marina stilligera Barneby

Marina unifoliata (B.L. Rob. \& Greenm.) Barneby

Mimosa affinis B.L. Rob.

Mimosa albida Humb. \& Bonpl. ex Willd.

Mimosa polyantha Benth.

Nissolia Jacq. sp.

Pachyrhizus erosus (L.) Urb.

Phaseolus lunatus L.

Piscidia grandifolia I.M.Johnst. var. glabrescens Sandwith

Pterocarpus Kuntze sp.

Rhynchosia minima (L.) DC.

Senna argentea (Kunth) H.S. Irwin \& Barneby

Senna racemosa (Mill) H.S. Irwin \& Barneby

Tephrosia vicioides Schltdl.

Zornia gemella Vogel

sp. 1

sp. 2

sp. 3

sp. 4

\section{KRAMERIACEAE}

Krameria cistoidea Hook. \& Arn.

LAMIACEAE

Asterohyptis mociniana Epling

Salvia misella Kunth

Salvia sessei Benth.

Salvia L. sp. 1

Salvia L. sp. 2

Salvia L. sp. 3

Salvia L. sp. 4

Salvia L. sp. 5

LOASACEAE

Mentzelia hispida Willd.

LYTHRACEAE

Cuphea wrightii A. Gray

MALPIGHIACEAE

Bunchosia canescens (Aiton) DC.

Galphimia glauca Cav.

Gaudichaudia albida Schltdl. \& Cham.

sp. 1

1

\section{1}

2

14

14

7

7

3

2

2

3

12

3

4

21

1

8

7

3

2

1

22

4

4
2

2
3

3

1

1

$$
1
$$$$
1
$$

X

X 1

6

6
14

X

1,2

$1,2,3$

1

1

1

8

3

2

X

X 4

X 8

X

1,3

X

1,2

1,3

$\begin{array}{llll}7 & X & & 2 \\ 1 & & X & \\ 3 & & & \\ 2 & & & \end{array}$


Appendix 1. Continuation.

\section{sp. 2}

TAXON

F1S FER ETB ETL GKB GKT

MALVACEAE

Anoda cristata (L.) Schltdl.

Ayenia berlandieri S. Watson

Heliocarpus velutinus Rose

Sida abutilifolia Mill.

Sida angustifolia Lam.

Sida anodifolia Fryxell

Sida michoacana Fryxell

$1 \mathrm{X}$

Triumfetta semitriloba Jacq.

Waltheria americana L.

Waltheria conzattii Standl.

MYRTACEAE

Psidium guajava L.

NYCTAGINACEAE

Commicarpus scandens (L.) Standl.

sp. 1

OLEACEAE

Fraxinus purpusii Brandegee

ONAGRACEAE

Hauya rusbyi Donn. Sm. \& Rose

OROBANCHACEAE

Buchnera elongata Sw.

Castilleja arvensis Cham. \& Schltdl.

Castilleja tenuiflora Benth.

Lamourouxia rhinanthifolia Kunth

PASSIFLORACEAE

Passiflora suberosa L.

Turnera L. sp.

PHYLLANTHACEAE

Phyllanthus L. sp.

POLEMONIACEAE

Loeselia coerulea G. Don

POLYGALACEAE

Polygala albowiana Chodat

Polygala compacta Rose

Polygala serpens S.F. Blake

1

$X$

$\begin{array}{ccccc}3 & & & & \\ 2 & & X & & 1,2 \\ 6 & X & & 1,2,3 & \\ 18 & & & 1 & \\ 10 & & & & \\ 2 & & & 1,2 \\ 9 & & & \\ 1 & & & \\ 23 & & 1,2 \\ 8 & X & & \end{array}$

$x$

RANUNCULACEAE

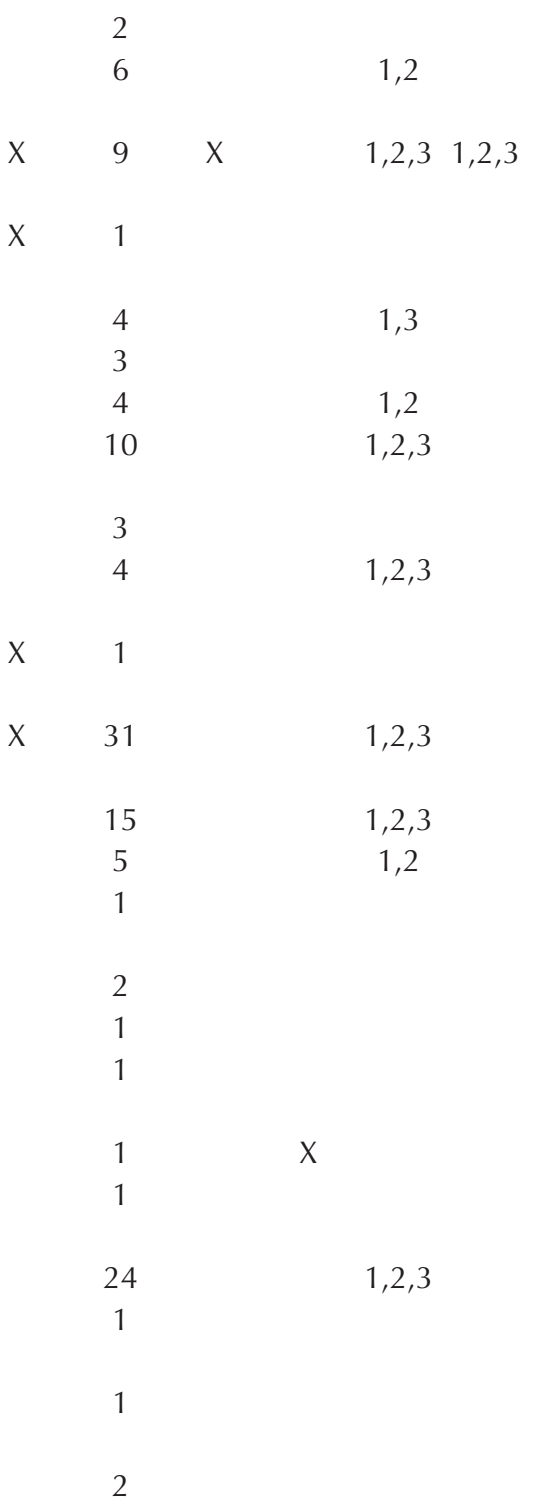

Clematis L. aff. drummondii

Clematis dioica L.

Thalictrum steyermarkii Standl.

RHAMNACEAE

Colubrina macrocarpa G. Don

Karwinskia humboldtiana (Schult.) Zucc.

RUBIACEAE

Crusea calocephala DC.

Crusea longiflora (Willd. ex Roem. \& Schult.)

W.R. Anderson

Crusea setosa (M. Martens \& Galeotti) Standl.

\& Steyerm

Galium uncinulatum DC. 


\begin{tabular}{|c|c|c|c|c|c|c|}
\hline TAXON & F1S & FER & ETB & ETL & GKB & GKT \\
\hline Gallium Mill. sp. & & 3 & & & & \\
\hline Richardia tricocca Standl. & & 2 & & & & \\
\hline \multicolumn{7}{|l|}{ RUTACEAE } \\
\hline Ptelea trifoliata L. & $x$ & 1 & & $x$ & & \\
\hline \multicolumn{7}{|l|}{ SAPINDACEAE } \\
\hline Cardiospermum halicacabum L. & $x$ & 10 & & & $1,2,3$ & \\
\hline \multicolumn{7}{|l|}{ SAPOTACEAE } \\
\hline Sideroxylon capiri (A. DC.) Pittier & $x$ & 1 & & $x$ & & \\
\hline \multicolumn{7}{|l|}{ SOLANACEAE } \\
\hline Datura stramonium L. & & 1 & & & & \\
\hline Physalis L. sp. & & 1 & & & & \\
\hline Solanum L. sp. & & 8 & $x$ & & 1,2 & \\
\hline \multicolumn{7}{|l|}{ VERBENACEAE } \\
\hline Lantana achyranthifolia Desf. & & 10 & & & $1,2,3$ & \\
\hline Lantana camara L. & & 3 & & & 1 & \\
\hline Lippia alba (Mill.) N.E. Br. ex Britton \& P. Wilson & & 1 & & & & \\
\hline Lippia dulcis Trevir. & & 17 & $\mathrm{x}$ & & $1,2,3$ & 2,3 \\
\hline Lippia graveolens Kunth & & 16 & $x$ & & $1,2,3$ & $1,2,3$ \\
\hline Priva aspera Kunth & & 2 & & & & \\
\hline Verbena elegans Kunth & & 2 & & & & \\
\hline \multicolumn{7}{|l|}{ VITACEAE } \\
\hline sp. 1 & $x$ & 1 & & & & \\
\hline
\end{tabular}


Appendix 2. Species from the top layer recognized as new arrivals in some sampling sites. PFR = presence of the species in the fragments: $1=1$ to $3 ; 2=4$ to $8 ; 3=9$ to $18 ; 4=19$ to $27 ; 5=28$ to 34 . Use type: $U-1=$ agriculture without residual vegetation; $\mathrm{U}-2$ = agriculture with residual vegetation; $\mathrm{U}-3=$ fallow periods of 8 to 10 years; $U-4=$ fallow periods of more than 10 years.

PFR FAMILY/SPECIE

FRAGMENT NUMBER

$122 \quad 3 \quad 5 \quad 2022 \quad 9 \quad 1011 \quad 1519232425283133 \quad 4 \quad 612 \quad 1314161826307881721272932 \quad 343536$

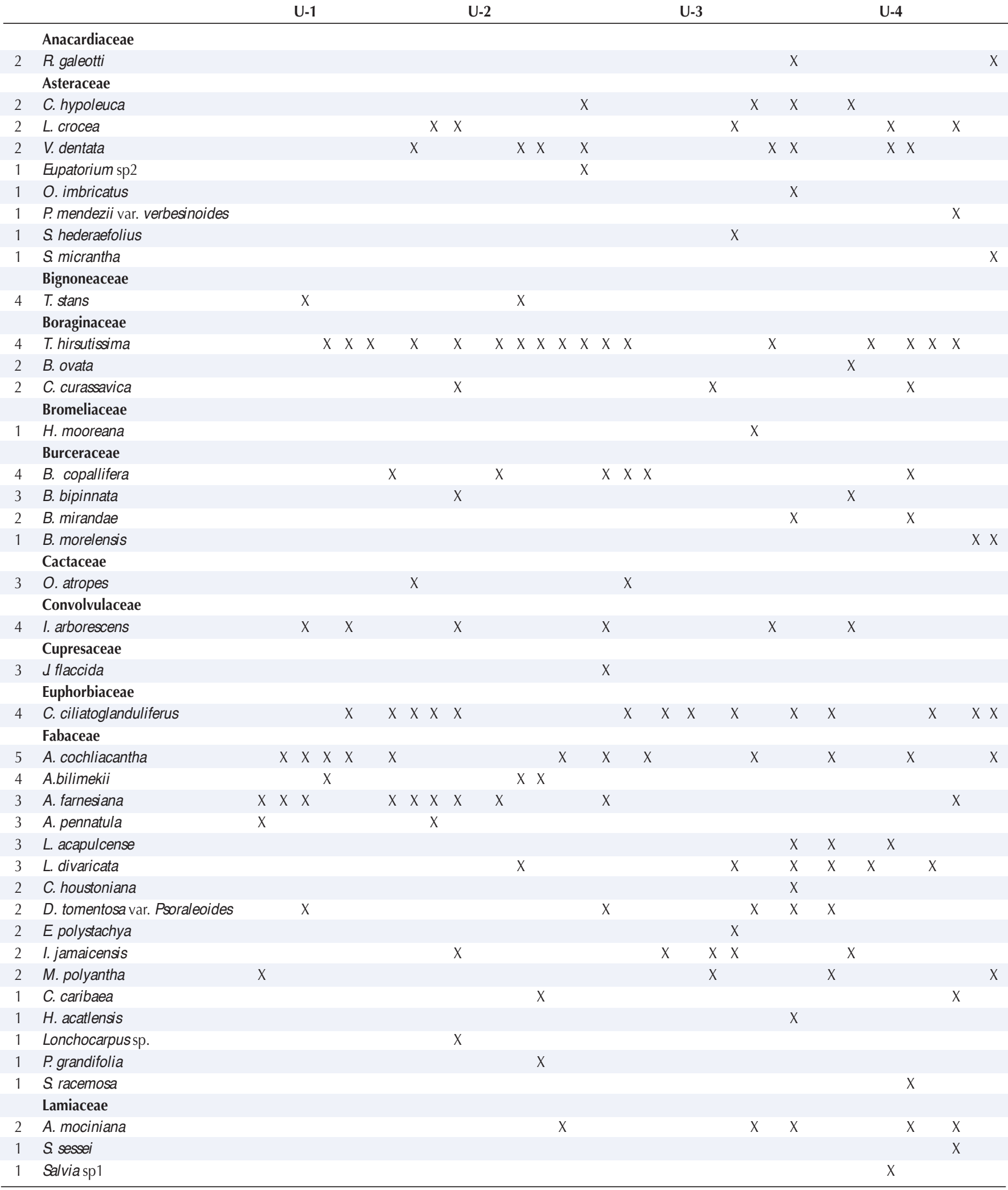

U-4 
Appendix 2. Continuation.

PFR FAMILY/SPECIE

FRAGMENT NUMBER

$123 \quad 3 \quad 52022 \quad 91011 \quad 151923242528313344 \quad 6121314161826307881721272932 \quad 343536$ U-1

U-2 U-3

U-4

Malpighiaceae

2 B. canescens Malvaceae

2 W. conzattii

2 H. velutinus

1 A. berlandieri Solanaceae

2 Solanum sp. Verbenaceae

3 L. dulcis Undetermined

2 Indeterminada 1

2 Indeterminada 9

1 Indeterminada 3

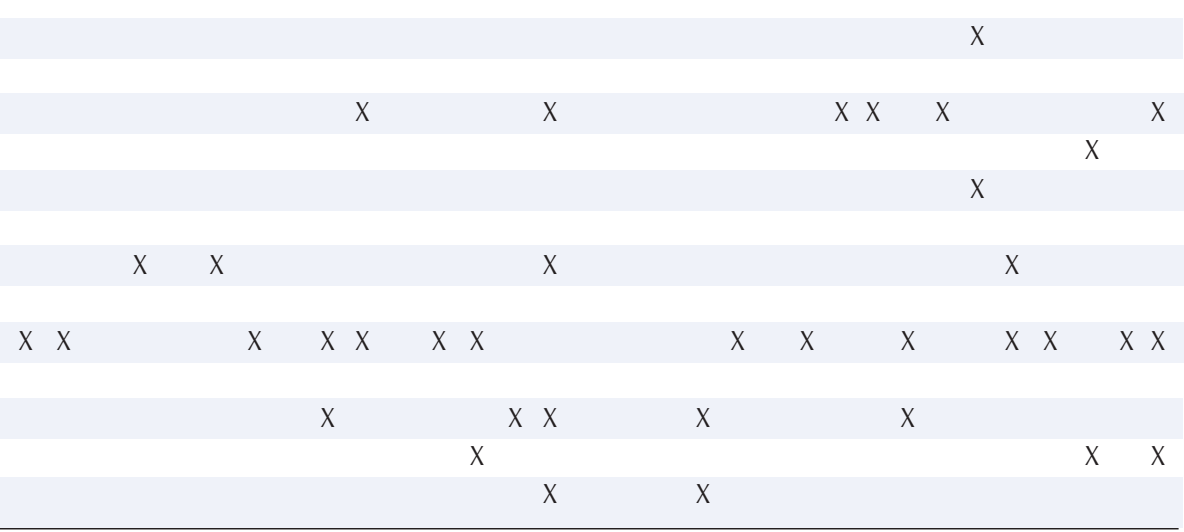

